Al-Fikra: Jurnal IImiah Keislaman, Vol. 16, No. 2, Juli - Desember, 2017 (203 232)

\title{
MAQASHID SYARI'AH HUKUM PERKAWINAN DALAM KOMPILASI HUKUM ISLAM (KHI)
}

\author{
${ }^{1} \mathrm{NURHADI}$ \\ ${ }^{1}$ Sekolah Tinggi Agama Islam (STAI) Al-Azhar Pekanbaru \\ alhadicentre@yahoo.co.id
}

\begin{abstract}
Existential and the position of Islamic law (Islamic law) in Indonesian national law is part of the national legal system itself. Therefore, Islamic law has an opportunity to contribute to the establishment and renewal of national law. The emergence of Marriage Law Number 1 year 1974 and Compilation of Islamic Law, is a proof of the result of the struggle for the existence of Islamic Sharia. The Compilation of Islamic Law $(\mathrm{KHI})$ is also a description that the law of marriage and inheritance and perwakafan is the legal field hablum min an-nas who get the normative legal provisions in detail in the regulation of national law in Indonesia. While the marriage law of Islam dominates, so that contains many articles in the Compilation of Islamic Law $(\mathrm{KHI})$ reached 170 Articles. In this case, the benefit and the harm in something is not necessarily relative. Their permissibility and prohibition can be determined by a concrete paradigm, not on the basis of human merit in the world alone. So the maintenance must be with the appropriate method of understanding the nash, not just a mere logical view, but with elastic theory in accordance with the progress of civilization and politics in a country or region. An example of the result of an elastic Islamic legal method with the advancement of Indonesian times and politics is the Compilation of Islamic Law. This research method uses qualitative concept, with normative juridical approach in in-concreto and legal synchronization, whereas research type of library of Risert (bibliography), data collection method is using primary and secondary data and technical data analysis is using contents analysis method with measuring instrument mashlahah (maqasid shariah). Islamic law has the goal of realizing the benefit of mankind (maqasid al-shariah) in the world and happiness in the afterlife. This embodiment is determined by the harmonization of relations between humans. The relationship is marriage, it is one of the media to know each other. The purpose of marriage in Islam is the guidance of human morality and humanize the moral, so the relationship between two different gender can build a new life culturally and socially. Maqashid shariah in marriage is hifzhu an-Nasl (maintaining offspring or honor) is at the level of hajiyat, then
\end{abstract}


marriage is a necessity, as the intention of human nature in pairs. Maqashid Sharia in the KHI on Marriage Law is hifzhu al-Nasl, at-Ta'aruf Ikhtiyar, Mitsaqan al-Ghalizhah, Mu'asyiru bi al-Ma'ruf. al-Hadal al-Hikmah, Hifzhu al-Maal li alHaqqihi, Haqqu al-Waalidi li al-Walidihi, ljbar li al-Waalidati, Haqqu al-Thaaliq li al-Zaujihi, Haqqu al-Zaujati li al-Zaujihi, while the core maqashidnya is Jalbu alMashalih wa dar'ul al-Mafasid (uphold kemaslahatan and refuse kemudratan).

Keywords: Maqashid Syari'ah, Hukum pernikahan, Kompilasi hukum islam

\section{PENDAHULUAN}

Sebagai bagian dari syariat Islam, kawin (nikah) merupakan satu di antara hukum yang berlaku bagi laki-laki dan perempuan sebagai mahluk yang diciptakan berpasangpasangan, hal ini dijelaskan dalam surah al-Hujarat 13 (Depag RI, 2005: 847).Anjuran nikah tersebut ditetapkan berdasarkan Alquran, Sunnah dan ljma' (Depag RI, 2005: 114). Pembahasan yang kompleks, mulai dari defenisi, rukun, syarat, tujuan, hikmah serta ketentuan nikah yang beragam (ikhtilaf/khilafiya), sehingga ada bab tersendiri dalam kajian IImu Fiqih, yang dikenal dengan Fiqih Munakahat.

Secaraeksistensial, kedudukan syariat atau hukum Islam dalam hukum nasional Indonesia merupakan sub sistem dari hukum nasional itu sendiri (Pancasila Sila ke 1).Karenanya, hukum Islam juga mempunyai peluang untuk memberikan sumbangan dalam rangka pembentukan dan pembaharuan hukum nasional, meski harus diakui problema dan kendalanya yang belum pernah usai sampai saat ini (A-Munawar, 2004: 14). Negara kestauan Indonesia beserta isi tumpa darahnya mengharapkan kehadiran fiqih Islam kelndonesiaan, hal ini sudah di contohkan oleh ulama Indonesia Mahmud Yunus yang mengarang tafsir al-Qur'an al-Karim (tafsir dan terjemhannya) pada tahun 1935 M/1354H (Jamal, 2017: 34). Karya Mahmud Yunus ini terasa sangat kental dengan nuansa keindonesiaan, terutama terkait dengan dinamika keadaan sosial masyakarat yang berkembang di era penulisannya. Tidak lain karena di dalamnya merupakan suatu ungkapan respon atas kondisi yang ada. Sehingga terlihat fungsi Al Qur'an yang up todate dan fleksibel terhadap zaman.Mahmud Yunus ingin memunculkan Al Qur'an sebagai kitab petunjuk yang sesungguhnya bagi kehidupan (Jamal, 2017: 43).

Keberadaan Undang-undang

Perkawinan No.1 tahun 1974 dan Kompilasi Hukum Islam atau yang lebih dikenal dengan istilah $\mathrm{KHI}$ merupakan salah satu bukti sekaligus hasil dari perjuangan eksistensi tersebut (A-Munawar, 2004: 14). Selain itu KHI menunjukkan bahwa hukum perkawinan dan kewarisan serta perwakafan menjadi bidang hukum dalam kemasyarakatan yang mendapatkan pengaturan normatif secara rinci dalam regulasi hukum di Indonesia, umat Islam melaksanakan Perkawinan memakai tiga system hukum yaitu Hukum Perdata Umum (KUHper), UU No. 1 Tahun 1974 tentang Perkawinan dan Kompilasi Hukum Islam (KHI). Dan ketentuan perkawinan yang sangat 
Al-Fikra: Jurnal IImiah Keislaman, Vol. 16, No. 2, Juli - Desember, 2017 (203 232)

detail diatur dalam banyak pasal dalam KHI (Buku I tentang Perkawinan).

Ketentuan nikah yang diatur dalam al-Qur'an merupakan salah satu bukti bahwa bukan hanya sebagai sebuah kitab agama dan ajaran-ajaran moral, al-Qur'an juga memuat unsur-unsur legislasi atau perudngan secara sistematis (Lihat mushaf al-Qur'an). Dalam mengemukakan pesan-pesannya, Nabi Muhammad Saw.secara terus terang ingin meninggalkan nilai-nilai dan institusi pra-Islam, tapi hanya sejauh ketika ia berusaha membangun sekali namun untuk selamanya sebagai dasar-dasar agama baru yang rahmata lil alamin (B. Hallaq, 2001: 4), yaitu Islam. Sehingga ditemukan beberapa hukum pada masa pra-Islam yang masih bertahan setelahnya namun dengan corak kelslaman (Lihat kitab Zabur, Taurat dan Injil). Sejalan dengan kaedah ushul "al muhafadhatu ala al-qadimi al-shalih wa al-akhdzu bi al-jadid al-ashlah" (A-Munawar, 2004: 4)

Kearifan syariat Islam juga didukung oleh fakta turunnya alQur'an secara berangsur-angsur yang dimaksudkan untuk menguatkan makna hukum (Asbabu an-Nujul/Maqshid Syariah/Hikmah Syariah/Falsafah), sehingga syariat sangat sesuai dengan psikologi umat, walaupun sikologi Islam di dasari dengan falsafah Islam (Khaidzir dan Anwar, 2017: 140). Karena turunnya tepat pada waktu diperlukannya keterangan hukum pada saat itu.Hal ini sekaligus memperjelas maksud atau tujuan hukum (Maqshid Syariah/Hikmah Syariah).Sehingga sebab-sebab turunnya al-Qur'an atau ashbabun nuzul tersebut dapat membantu dalam memahami dan menemukan tujuan ditetapkannya suatu hukum syariat (Zahrah, 2012: 102).

Hal ini menunjukkan bahwa sedikit banyaknya kebiasaan umat pada masa dan di tempat diturunkannya al-Qur'an mempengaruhi hukum yang terbentuk (Sosiologi Antropologi Hukum Islam) Termasuk dalam ketentuan nikah. Anjuran nikah bagi laki-laki dan perempuan tidak akan terlepas dari visi dan misi syariat Islam untuk mewujudkan kemaslahatan hidup manusia di dunia dan akhirat (Hizbul an-Nasl). Di dalamnya terkandung prinsipprinsip kebijaksanaan, kasih sayang, keadilan, dan kemaslahatan (Sabiq, 1980: 7-8).Aturan-aturan hukum bagi laki-laki dan perempuan yang sedang menjalani hidup rumah tangga yang tertuang dalam fiqih munakahat tentu memiliki relevansi dengan salah satu kemaslahatan yang ingin dicapai atau kemudaratan yang hendak dihindarkan (Hibzul adDin, an-Nafs dan al-Aql). Di sisi lain maqashid hukum Islam atau maqasid syariah dapat mempresentasikan hubungan antara hukum Islam dengan ide-ide terkini tentang hak-hak manusia, pembangunan dan peradaban (Auda, 2015: 32).

Nikah merupakan sebahagian dari akhlak yang mulia (akhlaku alkarimah), ahklak adalah hal yang mendasar dalam ajaran Islam, baik ahklak kepada Allah, sesama juga alam sekitarnya (Yatimin dan Thamrin, 2017: 155). Wahbah alZuhaili, seorang ulama fikih kontemporer kenamaan menyebutkan beberapa hikmah nikah, diantaranya untuk menjaga manusia laki-laki dan perempuan dari perbuatan yang terlarang (zina), 
menjaga kelangsungan hidup manusia, menjaga keturunan dan nasab, membentuk keluarga yang merupakan bagian dari masyarakat, untuk mengadakan tolong-menolong di antara pasangan suami-istri, menciptakan kecintaan di antara masyarakat dan menguatkan ikatan tali kekeluargaan dan dengan pernikahan pula akan membawa kemaslahatan dan menimbulkan rasa Tanggung jawab (Al-Zuhaili, 2004: 31). Hikmah-hikmah tersebut juga dapat ditemukan dalam banyak literatur fikih klasik (Fiqhus Sunnah, Said Sabiq, Hikmah Tasyri' wa Falsafatuhu, Ali Ahmad al-Jurjawi). Tidak dapat dipungkiri bahwa perkembangan sosial akan mempengaruhi suatu hukum yang berlaku di dalamnya. Karena, jika prinsip utama Islam diletakkan sebagai bagian dari kerangka makro, yakni institusi sosial sebagai proses kebudayaan, maka pertamatama yang perlu disadari bahwa institusi sosial tidak mungkin mengisolasikan diri dari perkembangan dan transformasi sosial, kultural maupun struktural. Karenanya cara pandang terhadap noktah-noktah ajaran Islam pun, dituntut secara terus-menerus melakukan penyesuaian dengan perkembangan masyarakat. Lebih dari itu, institusi Islam juga harus selalu memainkan peran strategis, terarah dan sejalan dengan karekteristik Islam selaku ajaran universal (A-Munawar, 2004: 201).

Wacana hukum Islam dan era globalisasi dalam konteks ini, untuk menjelaskan bahwa membicarakan hukum Islam dalam globalisasi itu justru sesuatu yang sangat relevan.Hukum Islam bukan sesuatu yang statis, tetapi mempunyai daya lentur yang dapat sejalan dengan arus globalisasi yang bergerak cepat (Syarifudin, 2005: 3).Hal ini dimaksud untuk menjaga kemaslahatan, menghilangkan kesempitan serta menolak bahaya sebagai tujuan adanya hukum syariat (Al-Zuhaili, 2014: 32).

Kemaslahatan dan bahaya dalam suatu hal tidak harus selalu relatif.Kebolehan dan pelarangannya masing-masing ditentukan oleh sebuah paradigma yang telah mapan, bukan atas dasar pertimbangan kemaslahatan manusia di dunia semata (B. Hallaq, 2001: 251). Sehingga dalam pemilaharaannnya tidak terlepas dari memahami nash hukum dengan benar, bukan hanya dengan pandangan nalar semata, malainkan dengan metode yang sesuai dengan perkembangan zaman dan politik disuatu Negara atau daerah (sosiologi Antropologi Hukum). Sebagai contoh hukum Islam hasil dari metode yang sesuai dengan perkembangan zaman dan politik di Indonesia adalah Kompilasi Hukum Islam (mengkodifikasi dan unifikasi hukum Islam).

Dari latar belakang yang cukup panjang diatas, yang mengandung lima unsur, yaitu wahyu, syariat, hukum dan undang-undang serta syiasyah (politik), maka dapat ditarik satu poin rumusan masalah dalam penelitian ini "bagaimana tinjauan filsafat hukum Islam (maqashid syariah) hukum perkawinan dalam Kompilasi Hukum Islam (KHI) ?

\section{KERANGKA TEORI}

\section{Maqashid Syariah (Filsafat} Hukum Islam)

Maqashid Syariah adalah tujuan Allah dan Rasul-Nya dalam merumuskan hukum-hukum Islam. Tujuan itu dapat ditelusuri dalam 
Al-Fikra: Jurnal IImiah Keislaman, Vol. 16, No. 2, Juli - Desember, 2017 (203 232)

ayat-ayat al-Qur'an dan Sunnah Rasulullah SAW sebagai alasan logis bagi rumusan suatu hukum yang berorientasi kepada kemaslahatan manusia dunia akhirat (Izzu al-Din, 1416H: 32), ini menjadi bukti insannya Allah kepada hambanya (jalbu al-mashalih wa dar'ul mafsid) (Zulkayandri, 2005: 31), Abu Ishaq al-Syatibi melaporkan hasil penelitian para ulama terhadap ayat-ayat al-Qur'an dan Sunnah Rasulullah SW bahwa hukum-hukum disyariatkan Allah SWT untuk mewujudkan kemaslahatan umat manusia, baik di dunia maupun di akhirat kelak (Effendi, 2005: 233). Kemaslahatan yang akan diwujudkan itu menurut al-Syatibi terbagi kepada tiga tingkatan, yaitu kebutuhan Dharuriyat, kebutuhan hajiyat, dan kebutuhan Tahsiniyat (Al-Syatibi, 1997: 324 dan Bahri, dkk, 2008: 72-73).Dilihat dari sudut kerasulan Nabi Muhammad SAW, dapat diketahui bahwa syariat Islam diturunkan oleh Allah adalah untuk mewujudkan kesejahteraan manusia secara keseluruhan (Alaiddin Koto, 2006: 121).

Kebutuhan yang pertama yaitu kebutuhan dharuriyat yang artinya tingkat kebutuhan yang harus ada atau disebut dengan kebutuhan primer. Bila tingkat ke-butuhan ini tidak terpenuhi,akan terancam keselamatan umat manusia baik didunia maupun di akhirat kelak (Nofialdi, 2009: 129). Menurut alSyatibi ada lima hal yang termasuk dalam kategori ini, yaitu memelihara agama, memelihara jiwa, memelihara akal, memelihara kehormatan dan keturunan, serta memelihara harta (Al-Ghazali, 1983: 286-287 dan Al-Syatibi, 1997: 10). Dengan demikian dapat dikatakan bahwa seseorang mukallaf akan bisa memperoleh kemashlahatan jika ia mempunyai kemampuan untuk menjaga lima prinsip di atas, dan sebaliknya ia akan mendapatkan kemudharatan atau Mafsadah jika ia tidak bisa menjaga lima hal tersebut (Nursidin, 2012: 8). Menurut Muhammad Said Ramadhan Al-Buthi untuk mewujudkan kemashlahatan tersebut, ada lima kriteria yang harus dipenuhi, yaitu: Pertama,memperiotaskan tujuantujuan syara', Kedua, tidak bertentangan dengan Al-Qur'an, Ketiga, tidak bertentangan dengan Al-Sunnah, Keempat, tidakbertentangan dengan prinsipqiyas, karena qiyas merupakan salah satu caradalam menggali hukum yang intinya adalah untuk memberikan kemashlahatan bagi mukallaf. Dan Kelima, memperhatikan kemashlahatan lebih besar yang dapat dicapai (Al-Buthi, 1997: 23).

Secara struktural, menjaga agama menempati poin pertama mengalahkan empat yang lain, maka semua hal yang mempunyai potensi destruktif terhadap agama akan menjadi pertimbangan paling utama. Untuk memelihara lima pokok inilah syariat Islam diturunkan. Setiap ayat hukum bila diteliti akan ditemuk analasan pembentukannya yang tidak lain adalah untuk memelihara lima pokok di atas (Al-Buthi, 1997: 24).

Kebutuhan Yang kedua adalah Kebutuhan hajiyat yang artinya kebutuhan-kebutuhan sekunder, di mana bilamana tidak terwujudkan tidak sampai mengancam keselamatannya, namun akan mengalami kesulitan. Syariat Islam menghilangkan segala kesulitan itu.Adanya hukum rukhshah 
(keringanan).Misalnya dalam ibadat sholat, ada hukum rukhshah, bilamana kenyataannya mendapat kesulitan dalam menjalankan (qashar jama').Dalam puasa jika dalam perjalanan jarak yang cukup jauh ada rukhshah, dengan syarat diganti pada hari yang lain (saki, haid, hamil dan melahirkan).

Tingkatan ketiga adalah kebutuhan Tahsiniyat. Kebutuhan tahsiniyat ialah tingkat kebutuhan yang apabila tidak terpenuhi tidak mengancam eksistensi salah satu dari lima pokok di atas dan tidak pula menimbulkan kesulitan. Tingkat kebutuhan ini berupa kebutuhan pelengkap, seperti dikemukakan alSyatibi, hal-hal yang merupakan kepatutan menurut adat istiadat, menghindarkan hal-hal yang tidak enak dipandang mata, dan berhias dengan keindahan yang sesuai dengan tuntutan norma dan akhlak (Al-Syatibi, 1997: 23). Al-Tahsiniyyat adalah tindakan atau sifat-sifat yang pada prinsipnya berhubungan dengan al-akhlak al-karim (norma/etika) yang dimaksudkan agar manusia dapat melakukan yang terbaik untuk penyempurnaan pemeliharaan lima unsur pokok. Artinya jika hal ini tidak dijaga maka akan timbul kekacauan. Misalnya: ibadah menutup aurat, suci dari najis. Islam menganjurkan memperbanyak ibadah sunnah (Effendi, 2005: 125).

\section{Hukum Perkawinan}

\subsection{Pengertian Perkawinan}

Perkawinanadalahpersekutuan hidup antara seorang pria dan seorang wanita yang dikukuhkan secara formal dengan UndangUndang, yaitu yuridis dan kebanyakan juga religius menurut tujuan suami istri dan UndangUndang, dan dilakukan untuk selama hidupnya menurut lembaga perkawinan (Tutik, 2006: 106). Dalam KUH Perdata, pengertian perkawinan tidak dengan tegas diatur ketentuannya seperti Pasal 26 yang memandang perkawinan hanya dalam hubungan-hubungan perdata dan Pasal 27 bahwa perkawinan menganut prinsip monogami. Pasal 103 menyatakan bahwa suami dan isteri harus saling setia, tolong menolong dan bantu membantu. Meskipun tidak dijumpai sebuah definisi tentang perkawinan, ilmu hukum berusaha membuat definisi perkawinan sebagai ikatan antara seorang pria dan seorang wanita yang diakui sah oleh perundangundangan negara dan bertujuan untuk membentuk keluarga yang kekal abadi (Nurhayani, 2015: 132).

Menurut Undang-Undang

Perkawinan Nomor 1 Tahun 1974 Pasal 1 ayat 2 perkawinan didefinisikan sebagai : "ikatan lahir batin antara seorang pria dengan seorang wanita sebagai suami isteri dengan tujuan membentuk keluarga, rumah tangga yang bahagia dan kekal berdasarkan Ketuhanan Yang Maha Esa" (UU No.1 Th 74).

Pencantuman berdasarkan Ketuhanan Yang Maha Esa adalah karena negara Indonesia berdasarkan kepada Pancasila sila yang pertama adalah Ketuhanan Yang Maha Esa. Sampai disini tegas dinyatakan bahwa perkawinan mempunyai hubungan yang erat sekali dengan agama, kerohanian sehingga perkawinan bukan saja mempunyai unsur lahir/jasmani tetapi juga memiliki unsur batin/rohani (STAIN Kudus: 8).

Sedangkan menurut Kompilasi Hukum Islam, seperti yang terdapat 
pada pasal 2 dinyatakan bahwa perkawinan dalam hukum Islam adalah, perkawinan yaitu akad yang sangat kuat atau mitsaqan ghalidhan untuk mentaati perintah Allah dan melaksanakannya merupakan ibadah. Kata mitsaqan ghalidhan ini ditarik dari firman Allah SWT yang terdapat pada Surat An-Nisa ayat 21 : Artinya : "Bagaimana kamu akan mengambil mahar yang telah kamu berikan kepada istrimu, padahal sebagian kamu telah bergaul (bercampur) dengan yang lain sebagai suami isteri. Dan mereka (istri-istrimu) telah mengambil dari kamu perjanjian yang kuat (mitsaqan ghalidhan)"(Departemen Agama RI: 81).

Dan menurut etimologi para ulama fikih mendefinisikan perkawinan dalam konteks hubungan biologis. Dibawah ini akan dijelaskan pengertian perkawinan menurut para ulama' fiqih sebagai berikut (Nuruddin, dkk, 2004: 38):

1) Imam Syafi'i mengartikan, pengertian nikah ialah suatu akad yang dengannya menjadi halal hubungan seksual antara pria dengan wanita sedangkan menurut arti majazi (mathoporic) nikah itu artinya hubungan seksual.

2) Hanafiah, "nikah adalah akad yang memberi faedah untuk melakukan mut'ah secara sengaja" artinya kehalalan seorang laki-laki untuk melakukan beristimta' dengan seorang wanita selama tidak ada factor yang menghalangi sahnya pernikahan tersebut secara syar'i.

3) Hanabilah nikah adalah akad yang menggunakan lafaz inkah yang bermakna tajwiz dengan maksud mengambil manfaat untuk bersenangsenang. AlMalibari mendefinisikan perkawinan sebagai akad yang mengandung kebolehan (ibahat) melakukan persetubuhan yang menggunakan kata nikah atau tazwij.

4) Muhammad Abu Zahrah didalam kitabnya al-ahwal alsyakhsiyyah, mendefinisikan nikah sebagai akad yang menimbulkan akibat hukum berupa halalnya melakukan persetubuhan antara laki-laki dengan perempuan, saling tolong-menolong serta menimbulkan hak dan kewajiban di antara keduanya.

Dari pendapat diatas definisi perkawinan dalam fikih dapat disimpulkan memberikan kesan bahwa perempuan ditempatkan sebagai objek kenikmatan bagi sang laki-laki. Yang dilihat pada diri wanita adalah aspek biologisnya saja. Ini terlihat dalam penggunaan kata alwat' atau al-istimta' yang semuanya berkonotasi seks (STAIN Kudus: 10).

\subsection{Dasar Perkawinan}

\subsubsection{Anjuran}

\section{MelaksanakanPerkawinan}

Dalam Al-Qur'an Allah telah menganjurkan umatnya untuk menikah dengan memberikan contoh bahwa sunnah para Nabi yang merupakan tokoh teladan mereka menikah. Allah berfirman dalam Surat Ar-Ra'd ayat 38: Artinya :"Dan sesungguhnya kami telah mengutus beberapa Rasulsebelum kamu dan kami memberikan kepada mereka isteriisteridan keturunan" (Departemen Agama RI: 81). Islam 
juga telah mengajarkan bahwa menikah dapat menghilangkan kesulitan dan memberikan kekuatan serta kecukupan untuk mengatasi kemiskinan (STAIN Kudus: 11). Allah berfirman dalam Surat An-Nur ayat 32: Artinya: "Dan nikahkanlah orangorang yang sendirian diantara kamu,dan orang-orang yang layak (berkawin) dari hambahambasahayamu yang lelaki dan hamba-hamba yang perempuan. Jikamereka miskin Allah akan memampukan mereka dengankarunia-Nya dan Allah Maha luas (pemberian-Nya) lagi Maha Mengetahui" (Departemen Agama RI: 354).

\subsubsection{Hukum \\ Perkawinan}

Melakukan

Hukum Islam mengenal lima kategori hukum yang lazim dikenal dengan sebutan al-ahkam alkhamsah (hukum yang lima) yakni: wajib (harus), sunnah atau mustahab atau tathawwu' (anjuran atau dorongan, atau sebaiknya dilakukan), ibahah atau mubah (kebolehan), karahah atau makruh (kurang atau tidak disukai, sebaiknya ditinggalkan) dan haram (larangan keras) (Suma, 2004: 91). Adapun pengertian dari kelima hukum tersebut adalah sebagai berikut:

a) Wajib (harus). Wajib yaitu perkawinan yang harus dilakukan oleh seseorang yang memiliki kemampuan untuk menikah (berumah tangga) serta memiliki nafsu biologis (nafsu syahwat) dan khawatir benar dirinya akan melakukan zina manakala tidak melakukan perkawinan. (Suma, 2004: 92). b) Sunnah. Perkawinan menjadi sunnah bila dilakukan seseorang dipandang dari faktor pertumbuhan jasmaninya sudah wajar dan cenderung untuk kawin serta bisa hidup mandiri (Tanjung, 2007: 141).

c) Ibahah atau mubah (kebolehan). Ibahah atau mubah yaitu perkawinan yang dilakukan tanpa ada faktor-faktor yang mendorong (memaksa) atau yang menghalanghalangi. (Suma, 2004: 93).

d) Karahah atau makruh (kurang atau tidak disukai, sebaiknya ditinggalkan). Perkawinan dikatakan makruh jika seseorang dilihat dari sudut pertumbuhan jasmani sudah pantas untuk kawin. Namun, ia belum ada kesanggupan untuk membiayai kehidupan keluarga setelah kawin (Tanjung, 2007: 142).

e) Haram (larangan keras).Perkawinan berubah menjadi haram jika perkawinan tersebut bertujuan tidak baik menganiaya pasangan atau perkawinan dengan muhrim, perempuan muslim dikawinkan dengan laki-laki nonmuslim, juga haram, begitu pula larangan untuk poliandri (Tanjung, 2007: 142).

\subsubsection{Tujuan Perkawinan}

Tujuan perkawinan adalah membentuk keluarga yang bahagia dan kekal.Untuk itu suami isteri saling membantu dan melengkapi, agar masing-masing dapat 
$\begin{array}{lrr}\text { mengembangkan kepribadiannya } \\ \text { membantu dan } & \text { mencapai } \\ \text { kesejahteraan spiritual dan } & \text { materiil } \\ \text { (Komariah, 2004: } & \text { 40). } & \text { Tujuan } \\ \text { perkawinan } & \text { masyarakat } & \text { adat } \\ \text { khususnya } & \text { yang } & \text { bersifat } \\ \text { kekerabatan } & & \text { adalah }\end{array}$

mempertahankan dan meneruskan garis keturunan, untuk kebahagiaan rumah tangga keluarga / kerabat, memperoleh nilai-nilai adat budaya dan kedamaian juga mempertahankan kewarisan (STAIN Kudus: 13). Berdasarkan Al-Qur'an Surat Ar-Rum ayat 21 tujuan perkawinan: 1). Berbakti Kepada Allah; 2). Memenuhi atau mencukupkan kodrat hidup manusia yang telah menjadi hukum bahwa antara pria dan wanita itu saling membutuhkan; 3). Mempertahankan keturunan umat manusia; 4). Melanjutkan perkembangan dan ketentraman hidup rohaniah antara pria dan wanita; 5). Mendekatkan dan saling menimbulkan pengertian antar golongan manusia antar golongan manusia untuk menjaga keselamatan hidup (Departemen Agama RI: 406).

\subsection{Rukun, Syarat Perkawinan 2.3.1 Rukun Perkawinan}

Rukun adalah sesuatu yang adanya menjadi syarat sahnya perbuatan hukum dan merupakan bagian dari perbuatan hukum tersebut.Rukun perkawinan berarti sesuatu yang menjadi bagian perkawinan yang menjadi syarat sahnya perkawinan (Naim, 2008: 67). Menurut jumhur Ulama rukun pekawinan ada lima dan masingmasing rukun itu memiliki syaratsyarat tertentu. Untuk memudahkan pembahasan maka akan diuraian rukun perkawinan, sebagai berikut (STAIN Kudus: 15): a) Calon mempelai laki-laki yang memenuhi syarat melaksanakan akad sendiri (Naim, 2008: 68): 1). Islam; 2). Baligh; 3). Berakal sehat: 4). Tidak dipaksa; 5). Bukan mahram calon mempelai wanita; 6). Tidak sedang ihram haji atau umrah; 7). Tidak mempunyai halangan yang mengharamkan nikah.

b) Calon mempelai perempuan atau wanita harus memenuhi syarat (Naim, 2008: 69): 1). Islam; 2). Berkal sehat; 3). Bukan mahram calon mempelai laki-laki; 4). Tidak sedang inram atau umrah; 5). Tidak mempunyai halangan yang meramkan nikah.

c) Wali adalah orang bertanggung jawab bertindak menikahkan mempelai wanita seuai syaratnya, yaitu (Nuruddin, dkk, 2004: 62): 1). Laki-laki; 2). Dewasa; 3). Mempunyai hak perwalian; 4). Tidak terdapat halangan perwalian.

d) Dua orang saksi sesuai syarat, yaitu: 1). Seorang laki-laki; 2). Muslim; 3). Adil; 4). Berakal sehat; 5). Baligh; 6). Mengerti maksud akad nikah; 7). Tidak terganggu ingatan; 8). Tidak tuna rungu atau tuli. Saksi harus hadir dan menyaksikan secara langsung akad nikah serta mendatangani akta nikah pada waktu dan ditempat akad nikah dilangsungkan (Nuruddin, dkk, 2004: 73).

e) Akad (ijab qabul), ljab adalah ucapan dari mulut wali untuk menunjukkan keinganannya membangun ikatan. Kabul adalah balasan dari ucapan 
wali oleh mempelai laki-laki (Mathlub, 2005: 34). Sesungguhnya beberapa ulama (fuqaha) berpendapat bahwa akad nikah itu dianggap terjadi secara sah dengan kata-kata zawajtu (aku jodohkan) atau ankahtu (aku kawinkan) dari calon pengantin perempuan atau walinya atau wakilnya (Ramulyo, 2005: 45). Adapun syarat akad (ijab qabul) adalah: 1). Dengan kata tazwij atau terjemahannya; 2). Bahwa antar ijab wali dan qabul calon mempelai lakilaki harus beruntun dan tidak berselang waktu; 3). Hendaknya ucapan qabul tidak menyalahi ucapan ijab, kecuali kalau lebih baik dari ucapan ijab; 4). Pihak-pihak yang melakukan akad harus dapat mendengarkan kalimat ijab qabul.

\subsubsection{Syarat Perkawinan}

Menurut Undang-undang bahwa untuk dapat melangsungkan perkawinan haruslah dipenuhi syarat-syarat pokok demi sahnya suatu perkawinan antara lain: syarat materiil dan syarat formil (Tutik, 2006: 117).

a. Syarat Materiil. Syarat materiil yaitu syarat mengenai orang-orang yang hendak melangsungkan perkawinan, terutama mengenai persetujuan, ijin dan kewenangan untuk memberi ijin (Komariah, 2004: 43). Syarat materiil diatur dalam Pasal $6 \mathrm{~s} / \mathrm{d} 11$ UU No. 1/1974 yang dapat dibedakan lagi dalam syarat materiil yang absolut/mutlak dan syarat materiil yang relatif/nisbi. Syarat materiil yang absolut/ mutlak merupakan syarat-syarat yang berlaku dan tidak membeda-bedakan dengan siapapun dia akan melangsungkan perkawinan meliputi syarat mengenai pribadi seorang yang harus diindahkan untuk perkawinan pada umumnya. Adapun syarat materiilnya berdasarkan UndangUndang Nomor 1 Tahun 1974 meliputi (UU No. 1 Th 74):

1) Batas umur minimum pria 19 tahun dan untuk wanita 16 tahun (Pasal 7 ayat 1 UU No. 1/1974). Dalam hal terdapat penyimpanagn dari batas umur tersebut dapat meminta dispensasi kepada pengadilan.

2) Perkawinan harus didasarkan atas perjanjian atau persetujuan antara kedua calon mempelai (Pasal 6 ayat 1 ).

3) Untuk melangsungkan perkawinan seorang yang belum mencapai umur 21 (dua puluh satu) tahun harus mendapat ijin kedua orang tua (Pasal 6 ayat 2).

Sedangkan syarat materiil yang relatif/nisbi, merupakan syarat yang melarang perkawinan antara seorang dengan seorang yang tertentu. Hal ini telah di atur dalam Undang-Undang Nomor 1 Tahun 1974 yaitu:

1) Larangan kawin antara orang-orang yang 
mempunyai hubungan keluarga, yakni hubungan kekeluargaaan karena darah dan perkawinan, yang ditentukan dalam Pasal 8 UU No.1/1974 (UU No. 1 Th 74):

a. Berhubungan darah dalam garis keturunan lurus kebawah ataupun keatas

b. Berhubungan darah dalam garis keturunan menyamping yaitu antara saudara, antara seorang saudara orang tua dan antara seorang dengan saudara neneknya

c. Berhubungan semenda, yaitu mertua, anak tiri, menantu dan ibu/bapak tiri

d. Berhubungan susuan, yaitu orang tua susuan, anak susuan, saudara sususan dan bibi/ paman susuan

e. Berhubungan saudara dengan isteri atau sebagai bibi atau kemeknekan dari isteri dalam hal seorang suami beristeri lebih dari seorang Mempunyai hubungan yang oleh agamanya atau peraturan lain yang berlaku, dilarang kawin (STAIN Kudus: 19).

2) Seorang yang masih terikat tali perkawinan dengan orang lain tidak dapat kawin lagi, kecuali seorang suami yang oleh pengadilan diijinkan untuk poligami karena telah memenuhi alasan-alasan dan syarat-syarat ditentukan (Pasal 9 UU No.1/1974)
3) Larangan kawin bagi suami dan isteri yang telah cerai kawin lagi satu dengan yang lain dan bercerai lagi untuk kedua kalinya, sepanjang hukum masing-masing agamanya dan kepercayaannya itu dari yang bersangkutan tidak menentukan lain (Pasal 10 UU No.1/1974) Larangan kawin seperti Pasal 10 tersebut sama dengan larangan kawin yang ditentukan dalam Pasal 33 $\mathrm{KUH}$ Perdata ayat 2 yang menentukan bahwa perceraian seteklah yang kedua kalinya antara orangorang yang sama, adalah terang.

4) Seorang wanita yang putus perkawinannya dilarang kawin kagi sebelum habis jangka tunggu (Pasal $11 \mathrm{UU}$ No. 1/1974).

b. Syarat Formil. Syarat formil atau syarat lahir (eksternal adalah syarat yang berhubungan dengan tata cara atau formalitas yang harus dipenuhi sebelum proses perkawinan (Tutik, 2006: 118). Adapun syaratsyaratnya berdasarkan PP No 9 Tahun 1975 sebagai berikut (PP No. 9 Th 1975):

1) Pemberitahuan akan dilangsungkannya perkawinan oleh calon mempelai baik secara lisan maupun tertulis kepada Pegawai Pencatat ditempat perkawinan sekurangkurangnya 10 (sepuluh) hari kerjasebelum perkawinan 


$$
\begin{aligned}
& \text { dilangsungkan (Pasal } 3 \\
& \text { dan } 4 \text { PP No. 9/1975). } \\
& \text { 2) Pengumuman oleh } \\
& \text { Pegawai Pencatatan } \\
& \text { dengan menempelkannya } \\
& \text { pada tempat yang } \\
& \text { disediakan di Kantor } \\
& \text { Pencatatan Perkawinan } \\
& \text { setelah Pegawai } \\
& \text { Pencatat meneliti syarat- } \\
& \text { syarat dan surat-surat } \\
& \text { kelengkapan yang harus } \\
& \text { dipenuhi oleh calon } \\
& \text { mempelai. Perkawinan } \\
& \text { tidak boleh } \\
& \text { dilangsungkan sebelum } \\
& \text { melewati hari ke } 10 \\
& \text { setelah diumumkan } \\
& \text { (Pasal } 10 \text { No.9/1975). } \\
& \text { Menurut Pasal } 57 \mathrm{KUH} \\
& \text { Perdata yang masih } \\
& \text { berlaku karena tidak } \\
& \text { diatur dalam UU No. } \\
& \text { 1/1974, pengumuman } \\
& \text { yang sudah melewati } 1 \\
& \text { (satu) tahun sedang } \\
& \text { perkawinan belum juga } \\
& \text { dilaksanakan, maka } \\
& \text { perkawinan menjadi } \\
& \text { kadaluwarsa dan tidak } \\
& \text { boleh dilangsungkan } \\
& \text { kecuali melalui } \\
& \text { pemberitahuan dan } \\
& \text { pengumuman baru. }
\end{aligned}
$$

\subsubsection{Syarat Sahnya Perkawinan}

Undang-undang perkawinan menyatakan bahwa perkawinan adalah sah apabila dilakukan menurut hukum masing-masing agama dan kepercayaan itu (Pasal 2 ayat 1) (UU No. 1 Th 74). Rumusan Pasal 2 ayat 1 beserta dengan penjelasannya itu menerangkan bahwa perkawinan mutlak harus dilakukan menurut hukum masingmasing agamanya dan kepercayaan itu, kalau tidak, maka perkawinan itu tidak sah (UU No. 1 Th 74).

Sedangkan Pasal 2 ayat 2 Undang-Undang Perkawinan menentukan bahwa tiap-tiap perkawinan dicatat menurut peraturan perundang-undangan semata-mata bersifata administrative (STAIN Kudus: 2), yang beragama Islam dilakukan oleh Pegawai Pencatat sebagai dimaksud dalam Undang-Undang Nomor 32 Tahun 1954 tentang Pencatatan Nikah, Talak dan Rujuk, sedangkan bagi mereka yang tidak beragama Islam, dulakukan oleh Pegawai Pencatat Perkawinan pada Kantor Catatan Sipil sebagaimana dimaksud dalam berbagai perundang-undangan mengenai pencatatan (Saleh, dikutip Supriyadi, 2015: 47). Pencatatn merupakan satu kesatuan yang tidak dapat dipisahkan, sehingga apabila salah satu unsur pasal tersebut tidak terpenuhi maka perkawinannya tidak sah (Wibowo, dikutip oleh Supriyadi, 2015: 47), adapun dasar argumentasi hukumnya adalah (Supriyadi, 2015: 48):

a. Pasal 2 (2)UUP telah dirumuskan secara organik oleh pasal 2 ayat (1) UUP yang pelaksanaannya diatur oleh pasal 3 s/d 9 PP 9/1975 tentang tata cara pelaksanaan UU perkawinan

b. Putusan Mahkamah Konstitusi No. 46/PUU$\mathrm{VIII/2010,} \mathrm{telah} \mathrm{menolak}$ permohonan uji materiil pasal 2 UUP, selanjutnya menyatakan setiap perkawinan diwajibkan untuk dicatatkan

c. KH Inpres No. 1/1991 dan Kemenag No. 154/1991 Pasal 5,6 dan 7 (1) memperkuat bahwa 
pencatatan menjadi syarat syahnya akad nikah

d. SE BAKN No. 48/SE/1990 tentang petunjuk pelaksanaan PP No. 45/1990 butir IX: istri PNS yang dinikah sah, yaitu sesuai dengan Pasal 2 (1) dan Pasal 2 (2) UUP.

Dan perkawinan yang memenuhi Pasal 2 ayat 1 dan ayat 2 merupakan perkawinan yang sah menurut agama dan peraturan perundangan yang berlaku di Indonesia (STAIN Kudus: 22).

\section{Kompilasi Hukum Islam}

Kompilasi Hukum Islam itu adalah ketentuan hukum Islam yang ditulis dan disusun secara sistematis menyerupai peraturan perundangundangan untuk sedapat mungkin diterapkan seluruh instansi Departemen Agama dalam menyelesaikan masalah-masalah di bidang yang telah diatur Kompilasi Hukum Islam (Arifin, KHI, MenAg dan MA R.I, 1987: 28). Oleh para hakim peradilan agama Kompilasi Hukum Islam digunakan sebagai pedoman/bahan pertimbangan dalam memeriksa, mengadili dan memutus perkara yang diajukan kepadanya (Abdurahman, 1992: 37).

Landasan Yuridis lahirnya $\mathrm{KHI}$ kembali pada rumusan tentang perlunya hakim memperhatikan kesadaran hukum masyarakat sebagaimana diisyaratkan oleh pasal 27 ayat 1 UU No. 14 tahun 1970. Selain itu, landasan fungsional $\mathrm{KHI}$ adalah fiqih Indonesia yang disusun dengan memperhatikan kondisi kebutuhan hukum umat Islam Indonesia, ia bukan merupakan suatu madzhab baru, melainkan ia mengarah kepada menyatukan (unifikasi) dari berbagai pendapat madzhab dalam hukum Islam, dan dalam rangka usaha menyatukan persepsi para hakim tentang hukum Islam menuju kepastian hukum bagi umat Islam (Abdurahman, 1992: 3-7).

Kompilasi Hukum Islam (KHI) merupakan kodifikasi dan unifikasi hukum Islam di Indonesia yang merujuk pada kitab-kitab fiqih (1) $A /$ Bajuri,(2)Fathul Muin dengan Syarahnya, (3) Syarqowi alat Tahrir, (4) Qulyubi/Muhallil, (5) Fathul Wahhub dengan Syarahnya, (6) Tuhfah, (7) Targhibul Musytaq, (8) Qawaninusy Syar'lyah lisayyid Utsman bin Yahya, (9) Qawaninusy Syar'iyah lisayyid Shodaqoh Dkhlan, (10) Syamsuri lil Faraidl, (11) Bughyatul Mustarsydin, (12) Al Fiqh 'ala Muadzahibil Arba'ah, Mughnil Muhtaj.Dari daftar Kitab-kitab ini, kita sudah dapat melihat pola pemiiran Hukum yang mempengaruhi penegakan Hukum Islam di Indonesia. Umumnya Kitab-kitab itu adalah kitab kuno dalam madzhab Syafi'l, kecuali No. 12 temasuk bersifat komperatif atau Perbandingan Madzhab (Kajian Diskusi (ISF), 2014: 4).

Upaya proses pembuatan $\mathrm{KHI}$ lebih konkretnya dimulai dari penerbitan Surat Keputusan Bersama (SKB) Hakim Agung dan Menteri Agama tanggal 25 Maret 1985 sampai terbitnya Inpres tanggal 10 Juni 1991 (InPres R.I. No. 1 Th 1991, 1996/97: iii-iv, 1-3). Kompilasi Hukum islam berjumlah 229 pasal, terdiri atas tiga kelompok materi hukum, yaitu Hukum Perkawinan (170 pasal; mulai pasal $1 \mathrm{~s} / \mathrm{d}$ pasal 170), Mengenai isi dari kompilasi hukum Islam terdapat tiga Bab pembahasan (1) Bab Pernikahan (2) Bab Waris dan (3) 
Bab Wakaf yang secara keseluruhan terakumulasi dalam 229 pasal. Secara terperinci Bab Pernikahan dapat di kemukakan secara singkat sebagai berikut: (a) Ketentuan Umum Pasal 1 (b)Dasar-dasar Perkawinan Pasal 2-10 (c) Peminangan Pasal 11-13 (d) Rukun dan Syarat perkawinan Pasal 14-29 (e) Mahar Pasal 30-38 (f) Larangan Kawin Pasal 39-44 (g) Perjanjian Perkawinan Pasal 45- 52 (h) Kawin Hamil Pasal 53-54 (i) Beristri lebih dari satu orang Pasal 55-59 (j) Pencegahan Perkawinan Pasal 6069 (k) Batalnya Perkawinan Pasal 70-76 (I) Hak dan kewajiban suami dan istri Pasal 77-84 (m) Harta Kekayaan dalam perkawinan Pasal 85-97 (n) Pemeliharaan Anak Pasal 98-106 (o) Perwalian Pasal 107-112 (p) Putusnya Perkawinan Pasal 113148 (q) Akibat Putusnya Perkawinan Pasal 149-169 (r) Rujuk Pasal 163169l (Kajian Diskusi (ISF), 2014: 5). Hukum Kewarisan termasuk wasiat dan hibah (44 pasal; mulai pasal 171 s/d pasal 214) dan Hukum Perwakafan (14 pasal; mulai pasal 215 s/d pasal 229), ditambah satu pasal ketentuan penutup yang berlaku untuk ketiga kelompok hukum tersebut (Amaliyah, wibesite.online.diakses.06.oktober.2 017).

\section{HASIL DAN PEMBAHASAN \\ 1. Maqashid Syariah Hukum Perkawinan dalam KHI}

Hukum Islam memiliki tujuan mewujudkan kemaslahatan manusia (maqasid al-syariah) di dunia dan kebahagiaan di akhirat.Perwujudan ini ditentukan oleh harmonisasi hubungan antara manusia baik secara individu maupun kolektif, serta hubungan manusia dengan alam sekitarnya (Departemen
Agama RI, 2005: 94).Hubungan tersebut seperti halnya dalam perkawinan, karena perkawinan merupakan salah satu media agar dapat saling mengenal antara yang satu dengan yang lain (Surah aHujarat 13). Hal ini menunjukkan bahwa Islam agama fitrah, sehingga pelarangan sesama jenis (LGBT) sudah sesuai fitrah manusia, LGBT juga terbukti menjadi salah satu penyebab munculnya penyakit HIV AIDS dan penyakit menular seksual (Anwar dan Wahyuni, 2017: 87). Juga Islam menganjurkan nikah agar terhindar dari penyimpanganpenyimpangan seksual senantiasaselalu terjadi, baik berupa delik perzinaan, lesbian maupun berbentuk homoseksual (Syarifuddin, 2010-2016: 105).

Hikmah yang terbesar dalam pernikahan ialah menjaga dan memelihara perempuan yang bersifat lemah dari kebinasaan (Saebani, 2009:19).Perempuan dalam sejarah digambarkan sebagai makhluk yang sekadar menjadi pemuas hawa nafsu kaum laki-laki atau Al-Istimta'u ditinjau dari aspek filologi berarti al-intifa'u yaitu mencari dan mengharap manfaatdan kelezatan (Hasanah, 2017: 58).Perkawinan adalah pranata yang menyebabkan seorang perempuan mendapatkan perlindungan dari suaminya (Sidqan, 1990: 7).Keperluan hidupnya wajib ditanggung oleh suaminya (Adtmoj, dkk, 1981: 333). Pernikahan juga berguna untuk memelihara kerukunan anak cucu (keturunan) (Dja'far Ami, 1977: 15), sebab kalau tidak dengan nikah, anak yang dilahirkan tidak diketahui siapa yang akan mengurusnya dan siapa yang bertanggung jawab menjaga dan mendidiknya (Al-Jurjawi: 117; terj 
Al-Fikra: Jurnal IImiah Keislaman, Vol. 16, No. 2, Juli - Desember, 2017 (203 232)

Idris, 2013: 219). Nikah juga dipandang sebagai kemaslahatan umum, akan terjaga shwat dari yang diharamkan (zina) (Sabiq, tth: 10), sebab kalau tidak ada pernikahan, manusia akan mengikuti hawa nafsunya sebagaimana layaknya binatang (Sabiq, tth: 10), dan denga sifat itu akan timbul perselisihan, bencana, dan permusuhan antara sesama manusia, yang mungkin juga dapat menimbulkan pembunuhan yang maha dasyat (Wahbah Juhaily: 40).

Tujuan pernikahan yang sejati dalam Islam adalah pembinaan akhlak manusia dan memanusiakannya serta menjauhkan dari perzinahan (Hasanah, 2017: 62), sehingga hubungan yang terjadi antara dua gender yang berbeda dapat membangun kehidupan baru secara sosial dan cultural (Sahrani, 2010: 7). Hubungan dalam bangunan tersebut adalah kehidupan rumah tangga dan terbentuknya generasi keturunan manusia yang memberikan kemaslahatan bagi masa depan masyarakat dan Negara (Abidin, dkk, 1999: 17). Dengan perkawinan maka tujuan dari Maqashid Syariah itu sendiri dapat terpenuhi yaitu dapat terjaganya keturunan-keturunan yang sah (Al-Jurjawi: 117; terj Idris, 2013: 218).

Maqashid syariah dalam hifzhu an-Nasl (memelihara keturunan atau kehormatan) adalah pada tingkatan hajiyat, maka menikah adalah keniscayaan, sebagai hajat fitrah manusia yang berpasang-pasangan (Surah al-Hujarat 13).Kaitan dengan permasalahan ini, bahwa syariat itu disyariatkan untuk kemaslahatan hamba dunia akhirat Al-Syatibi, 1997: 324), maka hukum juga demikian, sebab itu Kompilasi Hukum Islam tentunya mempunyai nilai-nilai filosofis yang mengandung kemaslahatan untuk seluruh umat Islam.Dalam kodifikasi serta unifikasi hukum Islam di Indonesia, secara hirarki hukum Kompilasi Hukum Islam termasuk menempati urutan paling akhir (Hirarki Perundangan Nasional).

\section{Analisis Maqashid Syariah dalam KHI tentang Hukum Perkawinan}

Kompilasi Hukum Islam yang terdiri dari tiga buku, Buku I tentang Perkawinan, Buku II tentang Warisan dan Buku III tentang Perwakafan. Dalam kajian peneliti kali ini adalah menganlisis $\mathrm{KHI}$ dalam Buku I tentang Perkawinan yang terdiri dari 19 Bab 170 Pasal, yang akan di analisis dengan pendekatan maqashid syariah (kemaslahatan). Dalam UU No. 1 Tahun 1974 tentang Perkawinan tidak memuat secara rinci pengaturan pernikahan secara syariat, maka UU No. 1 Tahun 1974 tentang Perkawinan ditafsirkan dengan KHI (Santoso, Alumni Pascasarjana IAIN Raden Intan Lampung). Analisis maqashid syariah dalam $\mathrm{KHI}$ tentang Hukum Perkawinan, sebagai berikut:

\subsection{Bab I tentang Ketentuan Umum}

Bab I KHI ini memuat tentang Ketentuan Umum terdiri dari 1 Pasal 1 ayat terdiri dari $10(\mathrm{a}-\mathrm{j})$.poin huruf (a) pemingan mengandung maqashid at-Ta'aruf antar sesama calon agar lebih mengenal satu sama lain (Surah al-Hujarat 13), pihak lak-laki mengandung maqashid agar kuat keinginan untuk secepatnya menikahinya (HR. Mutafaq alaih ttg Anjuran Nikah). 
Nurhadi; Maqashid Syari'ah Hukum Perkawinan Dalam Kompilasi Hukum Islam (KHI)

$\begin{array}{lrr}\text { Poin huruf } & \text { (b) } & \text { wali hakim } \\ \text { mengandung } & \text { maqashid } \\ \text { Ikhtiyar/upaya/solusi } & \text { bagi }\end{array}$ perempuan yang tidak memiliki wali sama sekali (HR. Ahmad 24205, Abu Daud 2083, Turmudzi $1021 \mathrm{ttg}$ wali). Poin huruf (c) akad nikah mengandung maqashid Mitsaqan alGhalizhah (ikatan kuat lahir dan bathin) (Surah an-Nisa 21 Depag RI: 120). Poin huruf (d) mahar mengandung maqashid Mu'asyiru bi al-Ma'ruf (menyenangkan hati istri) (Surah an-Nisa 19 Depag RI: 115). Poin huruf (e) taklik talak mengandung maqashid al-Adalah wa al-Hikmah (keadilan / kepastian / kebijaksanaan) (Surah an-Nisa 128 Depag RI: 143). Poin huruf (f) harta kekayaan dalam perkawinan / harta bersama / syirkah / mengandung maqashid Hifzhu al-Maal li alHaqqihi (memelihara harta yang menjadi haknya) (Poerwadarminta, 2003: 347 dan Susanto, 2008: 2 dan 72). Poin huruf (g) Pemeliharaan anak atau ahdhanah mengandung maqashid Haqqu al-Waalidi li alWalidihi (hak anak kepada orang taunya) (Surah Luqman ayat 1219Departemen Agama Rl:. 654-655). Poin huruf (h) perwalian mengandung maqashid ljbar li alWaalidati (perlindungan/melindungi perempuan yang belum dewasa (kecil), dan menjadi sarana komunikasi bagi perempuan yang sudah dewasa (baligh) (Azhari, 2015: abstrak). Poin (i) khuluk mengandung maqashid Haqqu alThaaliq li al-Zaujihi (hak minta cerai istri kepada suaminya/cerai gugat) (Surah al-Baqarah ayat 229 Departemen Agama RI: 55). Poin (j) mut'ah mengandung maqashid Haqqu al-Zaujati li al-Zaujihi (hak istri kepada suami/mantan suami)
(Surah al-Baqarah 228 Departemen Agama Rl: 55).

\subsection{Bab II tentang Dasar-dasar Perkawinan}

Bab II KHI ini berkaitan tentang Dasar-dasar Perkawinan terdiri dari 9 Pasal 15 ayat.Pasal 2 mengandung maqashid at-Ta'rif (defenisi/pengertian/makna).Pasal 3 mengandung maqashid al-Ghayah (finish akhir). Pasal 4 mengandung maqashid al-Shahih wa al-Haqq (kesahihan/sah/benar). Pasal 5 terdiri dari 2 ayat, ayat 1 mengandung maqashid al-Maslahah wal Ihtihsana al-Ammah (kemaslahatan dan kebaikan ummat/suami istri dan anakanak/keluaga), ayat 2 mengandung maqashid al-Ihtimal (tanggung jawab/tugas/melindungi). Pasal 6 terdiri dari 2 ayat, ayat 1 maqashidnya sama dengan ayat 2 Pasal 5 dan ayat 2 maqashidnya sama dengan ayat 1 Pasal 5. Pasal 7 terdiri dari 4 ayat, ayat 1 maqashidnya sama dengan ayat 2 Pasal 5, dan ayat 2,3,4 maqashidnya sama dengan ayat 1 Pasal 5. Pasal 8 mengandung maqashid al-Bayan wa al-Burhan (kejelasan dan klarifikasi). Pasal 9 terdiri dari 2 ayat, ayat 1 maqashidnya sama dengan Pasal 8, ayat 2 maqashidnya sama dengan ayat 1 Pasal 5. Pasal 10 maqashidnya sama dengan Pasal 8.

\subsection{Bab III tentang Peminangan}

Meminang berasal dari suku kata "khathaba-yakhthubu-khithbankhithbatan" (Ghazaly, 2003: 73-74). artinya menyatakan permintaan untuk menikah dari seorang laki-laki kepada seorang perempuan atau sebaliknya dengan perantaraan seseorang yang dipercayai (Sabiq, 
Al-Fikra: Jurnal IImiah Keislaman, Vol. 16, No. 2, Juli - Desember, 2017 (203 232)

tth: 20 dan Rasjid, 2009: 380 dan Hadi Mufaat, 1992: 2930).Meminang maksudnya seorang laki-laki meminta kepada seorang perempuan untuk menjadi istrinya dengan cara yang sudah umum berlaku di tengah-tengah masyarakat (Aziz Dahlan ed, 1997: 927-928 dan Ibrahim Lubis, tth: 343). $\mathrm{Bab}$ III KHI ini berisikan tentang Peminangan terdiri dari 3 Pasal 7 ayat. Pasal 11 maqashidnya sama dengan Pasal 1 huruf (a). Pasal 12 terdiri dari 4 ayat, ayat 1 maqashidnya sama dengan Pasal 1 huruf (a), ayat 2 dan 3 mengandung maqashid at-Tahrim (diharamkan/dilarang), ayat 4 maqashidnya al-lbahah (dibolehkan/berpilih). Pasal 13 terdiri dari 2 ayat, kedua ayat tersebut maqashidnya sama dengan ayat 4 Pasal 12.

\subsection{Bab IV Rukun dan Syarat Perkawinan}

Rukun adalah sesuatu perkara yang wajib dilaksanakan yang menentukan sah tidaknya suatu perbuatan atau ibadah dan ia berada di dalam perbuatan atau ibadah tersebut. Syarat adalah sesuatu perkara yang wajib dilaksanakan yang menentukan sah tidaknya suatu perbuatan atau ibadah dan ia berada di luar perbuatan atau ibadah tersebut (Haroen, 1996: 263 dan Seadie, 1996: 13). Bab IV KHI berkenaan dengan Rukun dan Syarat Perkawinan terdiri dari 5 Bagian 16 Pasal 28 ayat, yaitu: Bagian Kesatu : tentang Rukun Nikah, hanya 1 Pasal yaitu Pasal 14 maqashidnya sama dengan Pasal 4. Bagian Kedua : Calon Mempelai terdiri dari 3 Pasal. Pasal 15 terdiri dari 2 ayat, keduanya mengandung maqashid al-Maslahah wal Ihtihsana
al-Ammah (sama dengan ayat 1 Pasal 5). Pasal 16 terdiri dari 2 ayat, maqashidnya sama dengan Pasal 15). Pasal 17 terdiri dari 3 ayat, maqashidnya sama dengan Pasal 15 dan 16. Pasal 18 maqashidnya sama dengan Pasal 15, 16 dan 17. Bagian Ketiga : Waki Nikah terdiri dari 5 Pasal. Pasal 19 maqashidnya sama dengan Pasal 1 huruf (h). Pasal 20 terdiri dari 2 ayat, ayat 1 maqashidnya sama dengan Pasal 1 huruf (h) dan ayat 1 Pasal 5. Pasal 21 terdiri dari 4 ayat, maqashidnya sama dengan Pasal 20. Pasal 22 maqashidnya sama dengan Pasal 20, 21 dan Pasal 1 huruf (b). Pasal 23 terdiri dari 2 ayat, maqashidnya sama dengan Pasal 1 huruf (b). Bagian Keempat : Saksi Nikah, terdiri dari 3 Pasal. Pasal 24 terdiri dari 2 ayat, maqashidnya sama dengan Pasal 5 ayat 1 . Pasal 25 maqashidnya sama dengan Pasal 5 ayat 1 dan Pasal 4. Pasal 26 maqashidnya sama dengan Pasal 5 ayat 1. Bagian Kelima: Akad Nikah, terdiri dari 3 Pasal, pasal 27, 28, 29 ayat 1 dan 2 maqashidnya sama dengan Pasal 5 ayat 1 (al-Maslahah wal Ihtihsana al-Ammah), ayat 3 nya maqashidnya sama dengan Pasal 1 huruf (h) (Ijbar li al-Waalidati).

\subsection{Bab V tentang Mahar}

Pemberian wajib dari calon suami kepada calon istri sebagai ketulusan hati untuk meraih cinta kasih dalam bentuk benda atau jasa (Gazali , 2008: 84 dan Naruddin dan Tarigan, 2006: 66 dan Abdul Aziz, 2000: 1042).Bab V KHI ini bercerita tentang Mahar terdiri dari 9 Pasal 13 ayat. Pasal 30 mengandung maqashid sama dengan Pasal 1 huruf (d) dan huruf (j). Pasal 31, 32, 33 ayat 1-2 dan 34 ayat 1-2 mengandung maqashid sama 
Nurhadi; Maqashid Syari'ah Hukum Perkawinan Dalam Kompilasi Hukum Islam (KHI)

dengan Pasal 5 ayat 1 dan Pasal 12 ayat 4 (al-Ibahah). Pasal 35 maqashidnya sama dengan Pasal 1 huruf (d) (Mu'asyiru bi al-Ma'ruf) dan (j) (Haqqu al-Zaujati li al-Zaujihi) juga Pasal 12 ayat 4 (al-Ibahah). Pasal 36,37 dan 38 ayat $1-2$ maqashidnya sama dengan Pasal 5 ayat 1 (alMaslahah wal Ihtihsana al-Ammah).

\subsection{Bab VI tentang Larangan Kawin}

Larangan kawin atau nikah mempunyai dua makna, pertama bermakna orang-orang haram dinikahi (Surah an-Nisa 23 Departemen Agama RI: 120) dan makna kedua orang yang dilarang untuk dinikahi/pernikahan yang dilarang (Qadir Jawas, 2006: detail buku). Larangan perkawinan bagi seorang pria dengan seorang wanita selama-lamanya atau wanita-wanita yang haram dinikahi oleh seorang pria selama-lamanya mempunyai beberapa sebab (Zainuddin Ali, 2007: 30-31). Bab VI KHI ini tentang Larangan Kawin terdiri dari 6 Pasal 10 ayat. Pasal 39 ayat 1-3 mengandung maqashid hifzhu anNasl (memelihara keturunan dan kehormatan atau jalbu al-Mashalih wa dar'u al-Mafaasid) (i al-Haya'l yazdkuru al-Watha'u, lijtanibi alFasadi wa al-Fakhsyaa'l (malu menyebutkan jima', menjauhkan kerusakan dan bencana serta mara bahaya) (Ahmad al-Jurjawi: 298300). Pasal 40 terdiri dari 3 poin huruf (a-c), maka maqashidnya pada poin huruf $(a-b)$ sama dengan Pasal 39 (hifzhu an-Nasl), poin huruf (c) maqashidnya hifzhu al-Din, hifzhu an-Nafs, Hifzhu al-Aql wa hifzhu anNasl (memlihara kerusakan dan kebinasaan agama, diri, akal dan keturunan). Pasal 41 terdiri dari 2 ayat, maqashidnya sama dengan
Pasal 39. Pasal 42 mengandung maqashid sama dengan Pasal 5 ayat 1 (al-Mashlahah li an-Nisa). Pasal 43 terdiri dari 2 ayat, ayat 1 maqashidnya hifzhu an-Nasl, ayat 2 maqashidnya al-Ibahah wa alMashlahah Istihsana (boleh demi kemaslahatan dan kebaikan keduanya). Pasal 44 mengandung maqashid hifzhu al-Din, hifzhu anNafs, hifzhu an-Nasl (terjaga agama, jiwa dan kehormatan keturunan).

2.7 Bab VII tentang Perjanjian Perkawinan

Perjanjian perkawinan adalah suatu persetujuan yang dibuat oleh kedua calon mempelai pada waktu atau sebelum perkawinan dilangsungkandan masing-masing pihak akan berjanji untuk menaatiapa yang tersebut dalam hal persetujuan itu dan disahkan oleh pegawai pencatat nikah (Ghazaly, 2003: 119). Bila seseorang mengadakan janji kemudian ada oranglain yang menyetujui janji tersebut serta menyatakan pula suatu janji yang berhubungan dengan janji yang pertama, maka terjadilah perikatan dua buah janji dari dua orang yang mempunyai hubungan antara yang satu dengan yang lain (Suhendi, 2007: 45).

Perjanjian perkawinan diatur pada Bab VII KUH Perdata (BW) pasal 139 s/d 154 dan UU No. 1 Tahun 1074 tentang Perkawinan. Dan secara garis besar perjanjian perkawinan berlaku mengikat para pihak/mempelai apabila terjadi perkawinan, menyangkut harta kekayaan dan kepemilian masingmasing sebelum menjadi suami istri (harta bawaan gadis/bujang) (KUHPer Pasal 139 s/d 154). Lalu perbedaan keduanya hanya terletak pada keabsahan perjanjian perkawinan tersebut, kalau menurut 
Al-Fikra: Jurnal IImiah Keislaman, Vol. 16, No. 2, Juli - Desember, 2017 (203 232)

BW harus dilaksanakan dihadapan notaris sedangkan menurut UU No. 1 Tahun 1974 cukup dihadapan Pegawai Pencatat Nikah. Kemudian berlaku mengikat terhadap pihak ketiga jika sudah didaftarkan pada kepaniteraan Pengadilan Negeri tempat dimana perkawinan dilangsungkan, demikian menurut BW, sedangkan menurut UU No. 1 Tahun 1974 berlaku mengikat terhadap pihak ketiga sepanjang termuat dalam klausula / diperjanjikan dalam perjanjian perkawinan tersebut (BW dan KUHPer). Kemudian kedua system hukum tersebut ditafsirkan dengan $\mathrm{KHI}$ khusus untuk umat Islam, terletak pada Bab VII KHI ini mengulas tentang Perjanjian Perkawinan terdiri dari 8 Pasal 18 ayat. Pasal 45 terdiri dari 2 poin angka (1-2), maka maqashid dalam poin angka 1 adalah sama dengan Pasal 1 huruf (e), maqashid angka 2 sama dengan Pasal 5 ayat 1 (alMashlahah wa al-Istihsana). Pasal 46 ayat 1-3 maqashinya sama dengan Pasal 1 huruf (e) al-Adalah wa al-Hikmah wa al-Mashlahah, Pasal 47 ayat 1-3, Pasal 48-49 ayat $1-2$, Pasal 50 ayat $1-5$, Pasal 51 dan 52 mengandung maqashid hifzhu al-Maalal-Mashlahah wa al-Istihsana dan pada Pasal 52 ditambah dengan hifzhu an-Nafs.

\subsection{Bab VIII tentang Kawin Hamil}

Pengertian nikah hamil atau kawin hamil berarti pernikahan yang calon mempelai wanitanya dalam keadaan hamil sebelum adanya ijab qobul (zina) (Azis Dahlan, dkk., 1997: 507), anak yang dilahirkan disebut anak zina bernasab hanya kelbunya (Muhdlor, 1995: 59), baik yang menikahi yang menzinai atau tidak (Al-Gazali, 2003: 124). Di dalam Kitab Undang-Undang Hukum Perdata Pasal 32, menyatakan : "Seseorang yang dengan keputusan pengadilan telah dinyatakan melakukan zina, sekali-kali tidak diperkenankan kawin dengan pasangan zinanya itu (Team Nusantara, 2009: 5). Namun dalam Bab VIII KHI ini kasus tentang Kawin Hamil terdiri dari 2 Pasal 5 ayat membolehkanya (Dirjen Bimas Islam dan Penyelenggaraan Haji Depag RI, 2005: 16). Pasal 53 ayat 1-3 mengandung maqashid hifzhu alNasl wa an-Nafs (menjaga keturunan dengan pembuktian DNA dan memeliara jiwa lbu serta anaknya, agar tidak bunuh diri karena dosa zina dan dilarang menikah dengan pezinanya serta menggugurkan kandunganya) (. Ali Hasan, 1995: 96-99). Pasal 54 ayat 1-2 berkaitan dengan nikah sedang ihram, hal ini lari dari judul Bab VIII kawin hamil, seharusnya ada sub bahasan tersendiri, namun demikian ayat 1-2 Pasal ini mengandung maqashid al-Hurmatu baitullah wa bathnihi al-Haram al-Makkah (memulikan baitullah (ka'bah) dan tanah haram Makkah) (HR. Muslim).

\subsection{Bab IX tentang Beristri Lebih Dari Satu Orang}

Poligami berarti ikatan perkawinan yang salah satu pihak (suami) mengawini beberapa lebih dari satu istri dalam waktu yang bersamaan, bukan saat ijab qabul melainkan dalam menjalani hidup berkeluarga, sedangkan monogamy berarti perkawinan yang hanya membolehkan suami mempunyai satu istri pada jangka waktu tertentu (Al-Qamar Hamid, 2005: 19). Pada Bab IX KHI ini poligami yaitu Beristri Lebih Dari Satu Orang terdiri dari 5 Pasal 11 ayat. Pasal 55-56 ayat 1-3, 
Nurhadi; Maqashid Syari'ah Hukum Perkawinan Dalam Kompilasi Hukum Islam (KHI)

Pasal 57, Pasal 58 ayat 1-3 dan Pasal 59 semuanya mengandung maqashid hifzhu al-Din (terjauh dari prustitusi/perzinahan), hifzhu al-Nafs (meninggal karena penyakit Aids/HIV), hifzhu al-Nasl (semua perempuan punya naluri ingin menjadi Ibu dan punya anak keturunan) dan al-Mashlahah li alNIsaa'i/imraatun (kemaslahatan untuk perempuan secara umum) (Naluri Wanita Pro Pologamai), wa hifzhu al-Sahwah li al-Rijal (memlihara sahwat/nafsu laki-laki yang tinggi dari perzinahan) (Surah an-Nisa ayat 3 Departemen Agama $\mathrm{RI}:$ 115).

\subsection{Bab $X$ tentang Pencegahan Perkawinan \\ Pencegahan perkawinan}

adalah mencegah agar pernikahan jangan terjadi sementara syarat dan rukun atau hal-hal lainya yang mengakibatkan tidak tercapainya tujuan pernikahan (Zainuddin Ali, 2007: 33).Pencegahan perkawinan adalah menghindari suatu perkawinan berdasarkan larangan hukum islam yang diundangkan (Hamidjojo dan Pohan, 1991: 26). Pencegahan perkawinan dilakukan bila tidak terpenuhi dua persyaratan ini. Pertama, syarat materiil adalah syarat yang berkaitan dengan pencatatan perkawinan, akta nikah, dan larangan perkawinan.Kedua, syarat administratif adalah syarat perkawinan yang melekat pada setiap rukun perkawinan, yang meliputi calon mempelai laki-laki dan wanita, saksi, wali, dan pelaksanaan akad nikahnya (Ahmad Rafiq, 1998: 139).Dalam KHI Bab $X$ tentang Pencegahan Perkawinan terdiri dari 11 Pasal 17 ayat. Pasal 60 ayat 1-2, Pasal 61, Pasal 62 ayat 1-2, Pasal $63,63,64$ ayat 1-2, Pasal 65, 67, 68,
69 ayat $1-5$ semuanya mengandung maqashid jalbu al-Mashalih wa dar'ul mafasid (menegakkan kemaslahatan dan menolak kerusakan). Pada Pasal 62 ayat 1 dan Pasal 63 ada maqashid hifzhu al-Nasl dan Pasal 64 ada maqashid al-Shahih wa al-Haqq.

\subsection{Bab XI tentang Batalnya Perkawinan}

Batalnya perkawinan yaitu "rusak atau tidak sahnya perkawinan karena tidak memenuhi salah satu syarat atau salah satu rukunnya, atau sebab lain yang dilarang atau diharamkan oleh agama" (Tutik, 2008: 123). Batalnya perkawinan atau putusnya perkawinan disebut juga dengan fasakh (Ghozali, 2003: 141-142). Kata fasakh (batalnya pernikahan) berarti merusakkan atau membatalkan (Sahrani, 2009: 195196).Jadi, fasakh sebagai salah satu sebab putusnya perkawinan ialah merusakkan atau membatalkan hubungan perkawinan yang telah berlangsung (Azhar Basyir, 2010: 85). Batalnya perkawinan disebabkan adanya pencegahan perkawinan atau lainya (Abidin dan Aminudin, 1999: 73 dan Rasjidi, 1991: 83), seperti dalam Bab XI KHI ini berkaitan tentang Batalnya Perkawinan terdiri dari 7 Pasal 11 ayat. Pasal 70 huruf (a-e) mengandung maqashid sama dengan Bab VI tentang larangan kawin (Maqashid pada analisis $\mathrm{KHI}$ $\mathrm{Bab} \mathrm{VI}$ tentang larangan nikah/kawin). Pasal 71 huruf (a-f) maqashidnya sama dengan $\mathrm{Bab} X$ tentang pencegahan perkawinan (Maqashid pada analisis $\mathrm{KHI}$ Bab X tentang pencegahan perkawinan). Pasal 72 terdiri dari 3 ayat, ayat 1-2 mengandung maqashid hifzhu alNafs wa al-Nasl (menjaga jiwa dan 
Al-Fikra: Jurnal IImiah Keislaman, Vol. 16, No. 2, Juli - Desember, 2017 (203 232)

harga diri), ayat 3 ada didalamnya maqashid al-Mashalah. Pasal 73 huruf (a-d) dan Pasal 74 ayat 1-2 mengandung maqashid jalbu alMashalih (demi kemaslahatan). Pasal 75 ada maqashid hifzhu al-Nasl (menjaga garis keurunan).

\subsection{Bab XII tentang Hak dan Kewajiban Suami Istri}

Secara istilah pengertian hak adalah kekuasaan/wewenang yang dimiliki seseorang untuk mendapatkan atau berbuat sesuatu (Prasetyo, 2005: 60).Sementara menurut C.S.T Cansil hak adalah izin atau kekuasaan yang diberikan oleh hukum kepada seseorang (Cansil, 1989: 119-120).Menurut van Apeldoorn hak adalah hukum yang dihubungkan dengan seseorang manusia atau subyek hukum tertentu, dengan demikian menjelma menjadi suatu kekuasaan (Cansil, 1989: 119-120). Yang dimakssud dengan hak adalah apa-apa yang diterima oleh seseorang dari orang lain, sedangkan yang dimaksud dengan kewajiban adalah apa yang harus dilakukan seseorang terhadap orang lain (Syarifuddin, 2006: 159). Hak suami adalah kewajiban istri, sedangkan hak istri adalah kewajiban suami, kareana keduanya memiliki hak dan kewajiban secara seimbang walaupun lebih sedikit haknya suami dan lebih sedikit kewajiban istri (Surah al-Baqarah 228 Departemen Agama Rl: 123). Dalam Bab XII KHI ini berhubungan dengan Hak dan Kewajiban Suami Istri terdiri dari 6 Bagian 9 Pasal 29 ayat.Bagian Kesatu : Umum, terdiri dari 2 Pasal dan 7 ayat, maka pada Bagian kesatu ini mengandung maqashid al-Ghayatu li al-Nikahi ila ahli al-sakinah wa al-Mawaddah wa al-Rahmah (menjadi rumah tangga yang bahagia sejahtera dan harmonis). Bagian Kedua : Kedudukan suami Istri, hanya 1 Pasal, yaitu Pasal 79 ayat 1-3 terkandung nilai maqashid alMusawa (kesimbangan). Bagian Ketiga : Kewajiban Suami, hanya 1 Pasal yaitu Pasal 80 terdiri dari 7 ayat, ayat 1,2 dan 4 maqashidnya hifzhu al-Ahlih (menjaga dan melindungi keluarga), ayat 3 hifzhu al-Din (memlihara agama), ayat 5-6 maqashidnya al-lbahah al-Khair (boleh dan baik), ayat 7 maqashidnya hifzhu al-Nasl (menjaga kehormatan) secara kesluruhan 7 ayat tersebut mengandung hifzhu al-Din, al-Nasl, al-Nafs, al-Maal dan al-Aql.Bagian Keempat : Tempat Kediaman (Rumah/Tempat Tinggal), terdiri 1 Pasal yaitu Pasal 81 ada 4 ayat, kesemuanya mengandung maqashid hifzhu al-Ahlih wa al-Nasl (menjaga dan memeliahara keluarga, meliputi anak dan istri). Bagian Kelima : Kewajiban Sumi Poligami, ada 1 Padal 2 ayat, maqashidnya sama dengan Pasal 81 dan ditambah alAdalah (adil kepada para istri). Bagian Keenam : Kewajiban Istri, ada 2 Pasal dan terdiri dari 6 ayat, Pasal 83 ayat 1-2 ada didalamnya maqashid hifzhul al-Nasl wa al-Ahlih li al-lbadahwa al-Tsawab (menjaga rumah tangga dan berbakti kepada suami adalah Ibadah/pahala). Pasal 84 ayat 1-4 mengandung maqashid hifzhu al-Nasl wa yaqtha'u alNafaqah li al-Nusyuzihi (menajaga kehormatan suami serta memutuskan nafkah karena istri durhaka), juga mengandung maqashid at-Tarbiyah li al-Zaujihi (nasehat atau pelajaran untuk istri durhaka) (Surah an-Nisa 34 Departemen Agama RI: 123). 
Nurhadi; Maqashid Syari'ah Hukum Perkawinan Dalam Kompilasi Hukum Islam (KHI)

\subsection{Bab XIII tentang Harta Kekayaan Dalam Perkawinan}

Harta kekayaan adalah benda milik seseorang yang mempunyai nilai ekonomi (Abidin dan Aminuddin, 1999: 83).Dalam literatur hukum, benda adalah terjemahan dari istilah bahasa Belanda zaak, barang adalah terjemahan dari good, dan hak adalah terjemahan dari recht (Nuroniyah, 2011: 218).Menurut pasal 499 KHUPer, pengertian benda meliputi barang dan hak. Barang adalah benda berwujud (Ramulyo,1999: 188), sedangkan hak adalah benda tak berwujud (Muhammad, 1994: 10). Menurut Abdul Manan, bahwa "harta bersama adalah harta yang diperoleh selama ikatan perkawinan berlangsung dan tanpa mempersoalkan terdaftar atas nama siapa (Manan, 2006: 105).Dalam Bab XIII KHI ini bersangkutan dengan Harta Kekayaan Dalam Perkawinan terdiri dari 13 Pasal 24 ayat.Pasal 85 maqashidnya hifzhu al-Maal li al-Milk. Pasal 86-87 terdiri dari 2 ayat, maqashidnya sama dengan Pasal 85. Pasal 88 maqashidnya hifzhu alMaslahah.Pasal 89-90 maqashidnya hifzhu al-Maal li al-Milkaini (saling menjaga harta milik keduanya). Pasal 91 maqashidnya sama dengan Pasal 89-90. Pasal 92 maqashidnya hifzhu al-Maal li alMilkihi (menjaga harta miliknya sendiri).Pasal 93 terdiri dari 4 ayat, mengandung maqashid hifzhu alMaal li al-Syirkah (menjaga harta milik bersama). Pasal 94-95 terdiri dari 2 ayat, maqashidnya hifzhu alMaal li al-Milkihi wa milki al-Syirkati (menjaga harta milik sendiri dan bersama). Pasal 96 ada 2 ayat dan Pasal 97, maqashidnya hifzhu alMaal li al-Nisfihi/ha (menjaga harta miliknya dan bahagian dari warisanya).

\subsection{Bab XIV tentang Pemeliharaan Anak}

Hadhanah adalah kegiatan mengasuh, memelihara dan mendidik anak hingga dewasa atau mampu berdiri sendiri (Abdurrahman, 2004: 113). Hadhanah menurut bahasa adalah Al-Janbu berarti erat atau dekat (Tihami, dan Sahrani, 2010: 215), sedangkan menurut istilah memelihara anak laki-laki atau perempuan yang masih kecil dan belum dapat mandiri, menjaga kepentingan anak, melindungi dari segala yang membahayakan dirinya, mendidik rohani dan jasmani serta akalnya supaya si anak dapat berkembang dan dapat mengatasi persoalan hidup yang akan dihadapinya (Sabiq, 1984: 179 dan Rahmat, 2000: 224). Dalam Bab XIV $\mathrm{KHI}$ ini termaktub kewajiban Pemeliharaan Anak terdiri dari 9 Pasal 16 ayat. Pasal 98 ada 3 ayat dan 99 mengandung maqashid hifzhu al-Nasl wa al-Ahlihi li alMaslahah (menjaga keluarga dan keturunanya agar lenih baik). Pasal 100 maqashidnya hifzhu al-Nasl li Ummihi (menjaga nasab keturunan ibu).Pasal 101 maqashidnya hifzhu al-Nasl li al-Tahrimihi (menjaga kehormatan dengan sumpah). Pasal 102 ada 2 ayat maqasshidnya sama dengan Pasal 101. Pasal 103 ada 3 ayat mengandung maqashid hifzhu al-Nasl li al-Maslahah (menjaga keturunan demi kemaslahatan).Pasal 104 ada 2 ayat dan Pasal 105 mengandung maqashid hifzhu al-Nasl li al-Ahlihi (memelihara keturunan dan keluarganya). Pasal 106 mengandung maqashid hifzhu al- 
Al-Fikra: Jurnal IImiah Keislaman, Vol. 16, No. 2, Juli - Desember, 2017 (203 232)

Nasl li al-Maslahah (Surah at-Tahrim 6 Departemen Agama RI: 951).

\subsection{Bab XV tentang Perwalian}

Kata "wali" menurut bahasa berasal dari bahasa Arab, yaitu alWali dengan bentuk jamak Auliyaa yang berarti pecinta, saudara, atau penolong. Sedangkan menurut istilah, kata "wali" mengandung pengertian orang yang menurut hukum (agama, adat) diserahi untuk mengurus kewajiban anak yatim, sebelum anak itu dewasa; pihak yang mewakilkan pengantin perempuan pada waktu menikah (yaitu yang melakukan akad nikah dengan pengantin pria) (Djamaan Nur, 1993: 65). Kata wali dapat dipahami alasan hukum Islam menetapkan ayah sebagai orang yang paling berhak untuk menjadi wali bagi kepentingan anaknya, hal ini karena ayah adalah yang paling dekat dengan anaknya (Dedi Suprriyadi, 2009: 32-33). Dalam Bab $\mathrm{XV} \mathrm{KHI}$ ini pentingnya Perwalian terdiri dari 6 Pasal 13 ayat.Pasal 107 ada 4 ayat dan Pasal 108 mengandung maqashid hifzhu alWilayah li al-Walihi (menjaga dan menlindungi oaring yang jadi tanggunganya). Pasal 109 maqashidnya hifzhu al-Nasl wa alAhlihi (manjaga kehormatan dan keluarga). Pasal 110 ada 4 ayat, Pasal 111 ada 2 ayat dan Pasal 112, mengandung maqashid hifzhu alNasl wa al-Ahlihi wa al-Maalihi (menjaga keluarga dan hartanya) (Surah an-Nisa 2 dan 5 Departemen Agama RI: 114-115).

\subsection{Bab XVI tentang Putusnya Perkawinan}

Putusnya perkawinan karena kematian bukan disebabkan oleh kematian perdata, melainkan kematian jiwa suami atau istri (Hamidjojo dan Pohan: 123). Perceraian ialah penghapusan perkawinan dengan putusan hak, atau tuntutan salah satu pihak dalam perkawinan itu (Subekti, 2001: 42).Bab XVI KHI ini berkaitan dengan Putusnya Perkawinan terdiri dari 2 Bagian 35 Pasal 60 ayat.Bagian Kesatu : tentang Umum, terdiri dari 15 Pasal. Pasal 113 mengandung maqashid hifzhu alNafs, al-Nasl wa al-Maslahah (memelihara jiwa, keturunan/kehormatan dan untuk kemaslahatan). Pasal 114, 115 dan 116 mengandung maqashid hifzhu al-Nasl wa al-Maslahah (menjaga kehormatan keturunan dan untuk kemaslahatan). Pasal 117, 118, 119, 120 dan 121 mengandung maqashid hifzhu al-Nasl li al-Haqqi al-Jauzi li al-Tarbiyati al-Jauzatihili al-lbahati (memelihara keturunan karena talak hak suami dalam rangka mendidik istri hukumnya boleh).Pasal 122 ada maqashid hifzhu al-Nasl li al-Tahrim (menjaga keturunan dan diharamkan).Pasal 123 ada maqashid hifzhu al-Maslahati (menjaga kemaslahatan).Pasal 124 s/d 128 mengandung maqashid hifzhu al-Nasl li al-Maslahati li alAdalah (menjaga keturunan demi kemaslahatan suami istri demi keadilan).Bagian Kedua : Tata Cara Perceraian, terdiri dari 19 Pasal. Pasal 129-131 mengandung maqashid hifzhu al-Nasl li al-Haqqi Jauzili al-Maslahati (hak suami mentalak istri).Pasal 132-137 mengandung maqashid hifzhu alNasl li al-Haqqi Jauzatihili alMaslahati (hak istri untuk memfasakh suami atau menggugat suami). Pasal 138-143 mengandung maqashid hifzhu al-Nasl li al-Haqqi Jauzi wa Jauzatihi li al-Maslahati 
Nurhadi; Maqashid Syari'ah Hukum Perkawinan Dalam Kompilasi Hukum Islam (KHI)

(hak suami dan istri untuk saling meminta agar pernikahan dibatalkan/diputuskan). Pasal 144145 maqashidnya hifzhu al-Nasl alMaslahati.Pasal 146-147 ada maqashid hifzhu al-Maslahati.Pasal 148 maqashidnya sama dengan Pasal 132-137.

\subsection{Bab XVII tentang Akibat Putusnya Perkawinan}

Putus perkawinan adalah ikatan antara seorang pria dengan seorang wanita sudah putus.Putus ikatan berarti salah seorang diantara keduanya meninggal dunia, antara pria dengan seorang wanita sudah bercerai, dan salah seorang antara keduanya pergi ketempat yang jauh kemudian tidak ada beritanya sehingga pengadilan menganggap bahwa yang bersangkutan sudah meninggal (Hamid. 1996: 2829).Berdasarkan semua itu berarti ikatan perkawinan suami istri dapat putus dan atau bercerainya antara seorang pria dengan seorang wanita yang diikat dengan tali perkawinan (Zainuddin Ali. 2006: 73).Bab XVII $\mathrm{KHI}$ ini berkaitan dengan Akibat Putusnya Perkawinan terdiri dari 6 Bagian 13 Pasal 19 ayat.Bagian Kesatu : Akibat Talak, terdiri dari 4 Pasal. Pasal 149-152 mengandung maqashid hifzhu al-Nasl li al-Haqqi Jauzili al-Maslahati (hak suami mentalak). Bagian Kedua : Waktu Tunggu, ada 3 Pasal, yaitu Pasal 153-155 mengandung maqashid alHaqqu li al-Jauzi wa Jauzati li alMaslahati (iddah untuk kemaslahatan suami istri). Bagian Ketiga : Akibat Perceraian, ada 2 Pasal, yaitu Pasal 156-157 mengandung Maqashid hifzhu alNaslal-Haqqu li al-Jauzi wa Jauzati li al-Maslahati li al-Walihim (menjaga keluarga untuk kemaslahatan).
Bagian Keempat : Mut'ah, ada 3 Pasal, yaitu Pasal 158-160 mengandung maqashid hifzhu alNaslal-Haqqu li Jauzati li alMaslahati.Bagian Kelima : Akibat Khuluk, ada 1 Pasal yang maqashidnya al-Haqqu li Jauzati li al-Maslahati. Bagian Keenam : Li'an, ada 1 Pasal yang maqashidnya alHaqqu li al-Jauzi li al-Maslahati (hak suami untuk meli'an istri).

\subsection{Bab VIII tentang Rujuk}

Kata "Rujuk" menurut bahasa berasal dari kata masdar "Raja'a Yarji'u Rujuu'an waraja'atan" yang bermakna "Kembali" (Ibn Abidin, tt: 23) atau kembali kepada asal (M.Yunus, tt: 138). Dalam kamus besar bahasa Indonesia kata "Kembali" mempunyai beberapa arti sebagai berikut: Pertama, Baik menuju tempat semula, pulang, Kedua: Kembali kepada asalnya, Kembali, Ketiga: Uang kelebihan pembayaran, sekali lagi, berulang lagi (Abdilah, dan. Syarifudin, tt: 178). Ulama' Hanafiyah (Tanggungan milik yang terjadi pada masa iddah sebab kembalinya isteri pada suaminya dan kembalinya isteri kepada tingkah perbuatan yang pertama), Ulama' Syafi'iyyah ("Kembalinya wanita terhadap nikah dari talaq selain ba'in pada masa iddah pada arah yang khusus, atau pada jalan yang khusus), Ulama'Malikiyyah (Kembalinya isteri yang ditalaq tanpa selain memperbaiki akad), sedangkan menurut Ulama' Hanabillah (Kembalinya wanita yang ditalaq dari gairu ba'in terhadap sesuatu selain akad). Menurut Drs. H. Djaman Nur, rujuk adalah Mengembalikan status hukum perkawinan secara penuh setelah terjadinya thalaq raj'i yang dilakukan oleh bekas suami 
Al-Fikra: Jurnal IImiah Keislaman, Vol. 16, No. 2, Juli - Desember, 2017 (203 232)

terhadab bekas isterinya dalam masa iddah dengan ucapan tertentu (Djaman Nur, 1993: 174). Menurut Prof. Dr. Ahmad Rofiq, M.A., pengertian, rujuk adalah berasal dari bahasa Arab "raja'a -yarji'u-ruju'an" bentuk masdar artinya "kembali" istilah ini kemudian dibakukan dalam hukum perkawinan di Indonesia.Dalam pengertian rujuk adalah kembalinya suami kepada hubungan nikah dengan isteri yang telah dicerai raj'i dan dilaksanakan selama isteri masih dalam masa iddah (Ahmad Rofiq, 2003: 320).Bab VIII KHI ini tentang Rujuk terdiri dari 2 Bagian 7 Pasal 16 ayat.Bagian Kesatu : Umum, ada 4 Pasal, yaitu Pasal 163-166 maqashidnya alHaqqu li al-Jauzi li al-Maslahati (hak suami untuk merujuk ke istri). Bagian Kedua : Tata Cara Rujuk, terdiri dari 3 Pasal, yaitu Pasal 167-169 mengandung maqashid sama dengan Pasal 163-166 (hak suami untuk merujuk istri dengan cara yang baik).

\subsection{Bab XIX tentang Masa Berkabung}

Berkabung, dalam bahasa Arabnya adalah al hadaad ( ). Maknanya, tidak mengenakan perhiasan baik berupa pakaian yang menarik, minyak wangi atau lainnya yang dapat menarik orang lain untuk menikahinya (Ibnu Hajar, tth: 146). Pendapat lain menyatakan, alhadaad adalah sikap wanita yang tidak mengenakan segala sesuatu yang dapat menarik orang lain untuk menikahinya seperti minyak wangi, celak mata dan pakaian yang menarik dan tidak keluar rumah tanpa keperluan mendesak, setelah kematian suaminya (Al-Hamuud AnNajdi, $1415 \mathrm{H}$ : 8). Seorang istri yang ditinggal meninggal oleh suaminya, selain wajib menjalani masa 'iddah selama 4 buan 10 hari ia juga harus melalui masa berkabung dalam masa 'iddah tersebut (Syarifuddin, 2009: 320). Dalam Bab XIX KHI ini perlunya Masa Berkabung terdiri dari 2 ayat.Terdiri dari 1 Pasal mengandung maqashid hifzhu alNasl li al-Haqqi li al-Jauzati li alMaslahati nafsisha (menjaga kehormatan keluarga dan diri mantan istri al-Marhum).

\section{KESIMPULAN}

Hukum Islam memiliki tujuan mewujudkan kemaslahatan manusia (maqasid al-syariah) di dunia dan kebahagiaan di akhirat.Perwujudan ini ditentukan oleh harmonisasi hubungan antara manusia baik secara individu maupun kolektif, serta hubungan manusia dengan alam sekitarnya. Hubungan tersebut seperti halnya dalam perkawinan, karena perkawinan merupakan salah satu media agar dapat saling mengenal antara yang satu dengan yang lain. Tujuan pernikahan yang sejati dalam Islam adalah pembinaan akhlak manusia dan memanusiakannya, sehingga hubungan yang terjadi antara dua gender yang berbeda dapat membangun kehidupan baru secara sosial dan cultural.Maqashid syariah dalam hifzhu an-Nasl (memelihara keturunan atau kehormatan) adalah pada tingkatan hajiyat, maka menikah adalah keniscayaan, sebagai hajat fitrah manusia yang berpasang-pasangan.

\section{DAFTAR PUSTAKA}

Abd Rahman al-Gazali, Fiqih Munakahat (Bogor: Kencana, 2003)

,Fiqih Munakahat (Jakarta: Kencama, 2008) 
Nurhadi; Maqashid Syari'ah Hukum Perkawinan Dalam Kompilasi Hukum Islam (KHI)

Fiqh Munakahat, (Jakarta: Prenada Media, 2003)

Abdurahman, Kompilasi Hukum Islam di Indonesia (Jakarta: Akademika Pressindo, 1992)

Abdu El-Mun'im, (Bandung: Mizan Pustaka, 2015), Cet. I

Abdul Azis Dahlan, dkk., Artikel Hamil" dalam Ensiklopedi Hukum Islam, (Jakarta: Ichtiar Baru Van Hoeve, 1997)

Abdul Aziz Dahlan ed, Ensiklopedi Hukum Islam, (Jakarta, Ikhtiar Baru Van Hoeve Cet I, 1997)

Abdul Manan, Aneka Masalah Hukum Perdata Islam di Indonesia (Jakarta: Prenada Media Group, 2006).

Abdul Rahman Ghozali, Fiqh Munakahat, (Jakarta: Prenata Media Group, 2003)

Abdulkadir Muhammad, Hukum Harta Kekayaan (Bandung : Citra Aditya Bakti,1994)

Abdurrahman, Kompilasi Hukum Islam di Indonesia, (Jakarta: Akademika Presindo, 2004)

Abu Ishaq al-Syatibi, Al-Muwafaqat, (Bairut Darul Ma'rifah, 1997), juz I-II

Ahmad Hadi Mufaat, Fiqh Munakahat, Hukum Perkawinan Islam Dan Beberapa Permasalahannya, (Semarang: Duta Grafika, 1992)

Ahmad Azhar Basyir, Hukum Perkawinan Islam, (Yogyakarta: UII press, 2010)

Ahmad rafiq, Hukum Islam Di Indonesia , (Jakarta; rajawali pers, 1998)

,Hukum Islam di Indonesia, (Jakarta: PT. Raja Grafindo Persada, 2003), cet. VI

Ahmad Seadie, Penuntun Shalat Lengkap (Jakarta : Rica Grafika Jakarta, 1996)
Alaiddin Koto, IImu Fiqih dan Ushul Fiqih, (Jakarta: Rajawali Press, 2006)

Ali Ahmad al-Jurjawi, Hikmat alTasyri' wa Falsafatuhu (Haramian Singapore: Jeddah, tth) terjemahan Nabhani Idris, Indahnya Syriat Islam (Jakarta: Pustaka al-Kuatsar, 2013), cet. I

Al-Qamar Hamid, Hukum Islam Alternative Terhadap Masalah Fiqh Kontemporer, (Jakarta: Restu Ilahi, 2005)

Amir Syarifuddin, Hukum Perkawinan Islam Di Indonesia Antara Fiqh Munakahat dan Undang-undang Perkawinan, (Jakarta: Kencana, 2006 ...,Meretas Kebekuan ljtihad, Isu-Isu Penting Hukum Islam Kontemporer di Indonesia, (Jakarta: Ciputat Press, 2005), cet. II

Amiur Naruddin dan Azhari Akmal Tarigan,Hukum Perdata Islam Di Indonesia(Jakarta: Kencana, 2006)

Andi Tahir Hamid. Beberapa $\mathrm{Hal}$ Baru Tentang Peradilan Agama dan Bidangnya. (Jakarta : Sinar Grafika, 1996)

Abdul Haris Naim, Fiqh Munakahat, (Kudus: Sekolah Tinggi Agama Islam Negeri Kudus, 2008)

Abdul Majid Mahmud Mathlub, Panduan Hukum Keluarga Sakinah, (Solo: Era Intermedia, 2005)

Depag RI, Al-Qur'an dan Terjemahannya Departemen Agama Rl, (Proyek Pengadaan Kitab Suci Al-Qur'an, Bandung)

Amiur Nuruddin dan Azhari Akmal Tarigan, Hukum Perdata Islam di Indonesia, (Jakarta: Kencana Prenadamedia Group, 2004)

Armaidi Tanjung, Free Sex No Nikah Yes, (Jakarta: Amzah, 2007) 
Al-Fikra: Jurnal IImiah Keislaman, Vol. 16, No. 2, Juli - Desember, 2017 (203 232)

Beni AhmadSaebani, Fiqih Munakahat Juz 1, (Pustaka Setia, Bandung, 2009)

Busthanul Arifin, "Pelaksanaan Kompilasi Hukum Islam", pidato penyerahan 3 buku Kompilasi Hukum Islam kepada Menteri Agama dan Ketua Mahkamah Agung R.I., (Jakarta tanggal 26 Desember 1987)

Dahlan Abdul Aziz, Ensklopedi Hukum Islam (Jakarta: Ikhtiar Baru, 2000)

Dedi Suprriyadi, Fiqih Munakat Perbandingan, Pustaka Setia,2009)

Departemen Agama RI, Al-Qur'an dan Terjemahan (Semarang: Toha Putra, 2005)

Dirjen Bimas Islam dan Penyelenggaraan Haji Departemen Agama Republik Indonesia, Draf Kelima Hukum Terapan Peradilan Agama Bidang Perkawinan (Jakarta: Depag RI, 2005)

Dja'far Ami, Khutbah Nikah, (Pekalongan: Raja Murah, 1977) Djamaan Nur, Fiqih Munakahat, (Semarang: Dina Utama Semarang,1993)

Faisal Azhari, Tinjauan Maqashid AlSyari'ah Sebagai Hikmah AlTasyri' Terhadap Hukum Wali Dalam Pernikahan (Studi Komparatif Pandangan Imam Hanafi Dan Imam Syafi'i Dalam Kajian Hermeneutika Dan Lintas Perspektif), (Skripsi.Jurusan AlAhwal Al-Syakhshiyyah, Fakultas Syariah, Universitas Islam Negeri Maulana Malik Ibrahim Malang, 2015), hlm.abstrak.

Ghilman Nursidin, Konstruksi Pemikiran Maqashid Syariah Imam Al-Haramain Al-Juwaini (Kajian Sosio-Historis), (Tesis
Program Pascasarjana Institut Agama Islam Negeri (lain) Walisongo Semarang, 2012, Tidak Terbit)

Khairunnas Jamal, Wawasan Keindonesiaan Dalam Tafsir Al Qur'an Al Karim Karya Mahmud Yunus (Fakultas Ushuluddin Universitas Islam Negeri Sultas Syarif Kasim Riau, Al-Fikra: Jurnal IImiah Keislaman, Vol. 16, No. 1, Januari - Juni, 2017 (28-44).

Khairil Anwar dan Sri Wahyuni, Penerapan Mental Kognitif Islam Dan Psikososial Islam Dalam Mencegah Perilaku Lgbt Pada Remaja Muslim Pekanbaru (Program Pasca Sarjana UIN Sultan Syarif Kasim Riau Fakultas Psikologi UIN Sultan Syarif Kasim Riaueying74@yahoo.com, AlFikra: Jurnal Ilmiah Keislaman, Vol. 16, No. 1, Januari - Juni, 2017 (85-98).

Khaidzir dan Anwar, Gagasan Gerakan Psikologi Islam: Suatu Pendekatan Psikometrik (Universiti Kebangsaan Malaysia Program Pasca Sarjana UIN Sultan Syarif Kasim Riau eying74@yahoo.com, izay@ukm.my, Al-Fikra: Jurnal Ilmiah Keislaman, Vol. 16, No. 1, Januari - Juni, 2017 (137-151).

H. Arso Sosro Adtmojo dan H. A. Wasit Aulawi, Hukum Perkawinan di Indonesia, (Jakarta: Bulan Bintang, 1981), Cet. III

H. Djaman Nur, Figh Munakohat, (Semarang: Cv Toha Putra, cet.I, 1993)

Hakim Rahmat, Hukum Perkawinan Islam, (Bandung: Pustaka Setia, 2000) 
Nurhadi; Maqashid Syari'ah Hukum Perkawinan Dalam Kompilasi Hukum Islam (KHI)

Happy Susanto, Pembagian Harta Gono-Gini Setelah Terjadinya Perceraian, (Jakarta: Visimedia, 2008)

Hendi Suhendi, Fiqih Muamalah, (Jakarta, RajaGrafindo Persada, 2007)

Ibn Abidin, Raddul Mukhtar, (Dar Kutub al-Alamiyyah, tt).,juz.V

Ibnu Hajar, Fathul Bari, (Mesir: AlMaktabah As-Salafiyah, ttp, tth), hlm. Juz III

Ibrahim Lubis, Agama Islam Suatu Pengantar, (Jakart: Galia Indonesia, tth)

Imam Abi Hamid Muhammad bin Muhammad Al-Ghazali, AlMustashfa min 'Ilm Al-Ushul, (Beirut, Dar Al-Kutub AlIlmiyyah, 1983), juz I

Irfan Sidqan, Fiqh Munakahat, (Surabaya: Biro Pengembangan Perpustakaan dan Penerbitan Fak Syari'ah, 1990), Vol. I

Instruksi Presiden R.I. Nomor 1 Tahun 1991, Kompilasi Hukum Islam (Jakarta: Departemen Agama R.I., 1996/97), hlm. iii-iv

J.C.T. Simorangkir, Rudy T. Erwin, J.T. Prasetyo, Kamus Hukum, (Jakarta: Sinar Grafika, 2005), cet. VI

Jasser Auda, Maqasid Syariah As Philosophy Of Islamic Law: A System Approach: Membumikan Hukum Islam Melalui Maqasid Syariah, Penerjemah Rosidin

Komariah, Hukum Perdata, (Malang: Universita Muhammadiyyah Malang, 2004)

Lexy J. Meleong, Metode Penelitian Kualitatif, (Bandung: Remaja Rosda Karya, 2011)

Lili Rasjidi, S.H., LLM, Hukum Perkawinan Dan Perceraian Di Malaysia dan di Indonesia,
(Bandung: Remaja Rosda Karya, 1991)

M. Ali Hasan, Masa'il Fiqhiyah alhaditsah (Jakarta: PT. Rajagrapindo, 1995), cet.

M.Yunus, Kamus Arab Indonesia, (Jakarta: Hida Karya Agung, tt)

M. Yahya Harahap, "Materi Kompilasi Hukum Islam" dalam Dadan Muttaqien et. al. (eds.), Peradilan Agama \& Kompilasi Hukum Islam dalam Tata Hukum Indonesia (Yogyakarta: UII Press, Edisi 2, 1999)

Mohd. Idris Ramulyo, Hukum Perkawinan Islam (Jakarta: Bumi Aksara, 1999)

Moh. Idris Ramulyo, Hukum Perkawinan Islam, (Jakarta: PT Bumi Aksara, 2005)

Muhammad Amin Suma, Hukum Keluarga Islam di Dunia, (Jakarta: Rajawali Pers, 2004)

Muhammad Abu Zahrah, Ushul Fiqh, Penerjemah Saefullah Ma"shum, dkk, Cet. XVI, (Jakarta: Pustaka Firdaus, 2012)

Muhammad Al-Hamuud An-Najdi, AlKalimaat Al-Bayyinaat Fi Ahkam Hadaad Al-Mukminat, (Dar AlFath, Tahun 1415 H), Cet. I

Muhammad Said Ramadhan AlButhi, Al-Dhawabit Al-Mashlahat fi As-Syariah Al-Islamiyah, (Beirut, Muasasah Al-Risalah, 1997)

Mukhtar, Metode Praktis Penelitian Deskriptif Kualitatif, (Jakarta: Referensi, 2013)

Nasrun Haroen, Usul Fiqh I, (Jakarta: Logos Publishing House, 1996)

Neng Yani Nurhayani, Hukum Perdata, (Bandung: Pustaka Setia, 2015)

Noeng Muhajir, Metodologi Penelitian Kuantitatif, 
Al-Fikra: Jurnal IImiah Keislaman, Vol. 16, No. 2, Juli - Desember, 2017 (203 232)

(Yogyakarta: Rake Sarasin, 1989)

Nofialdi, Maqasid Al-Syari'ah Dalam

Perspektif Syatibi, (STAIN

Bukittinggi, Al-Fikra: Jurnal

Ilmiah Keislaman, Vol 8, No 1 (2009) dan Vol 15, No 2 (2016)

Pius Abdilah, dan. Anwar Syarifudin, Kamus Mini Bahasa Indonesia, (Surabaya: Arkola, tt)

Poerwadarminta, Kamus Umum Bahasa Indonesia, (Jakarta : Balai Pustaka, 2003)

Rekso Wibowo, Dikutip oleh Supriyadi, Dasar-Dasar Hukum Perdata di Indonesia, (Kudus: CV. Kiara Science, 2015)

Repository STAIN Kudus, Hukum Perkawinan, http://eprints.stainkudus.ac.id

Said Agil Husein al-Munawar, Hukum Islam dan Pluralitas Sosial, (Jakarta: Pena Madani, 2004), cet. I

Supriyadi, Dasar-Dasar Hukum Perdata di Indonesia, (Kudus: CV. Kiara Science, 2015)

Satria Effendi, Ushul Fiqih, (Jakarta:Kencana, 2005)

Sayyid Sabiq, Fiqh Sunnah, (Bandung: Al-Ma'aruf, 1984), Juz VIII

Fiqh Sunnah, (Beirut : Darul Fikr, tth), Jilid 2 , Fiqh Sunnah, (Cairo: Darul as-Sunnah, tth), Juz III Fiqih Sunnah (Bandung: PT Alma'arif 1980), juz V

Syarifuddin, Tinjauan Fiqh Terhadap Homoseksual, Dosen Fakultas sains dan Teknologi UIN Suska Riau, Al-Fikra: Vol 9, No 1 (2010) dan Desember Vol 15, No 2 (2016)

Slamet Abidin dan H. Aminudin, fiqih munakahat II (Bandung: Pustaka setia, 1999)
Fiqh Munakahat (Bandung : Pustaka Setia, 1999)

Soerjono Soekanto dan Sri Mamudji, Penelitian Hukum Normatif SuatuTinjauan Singkat (Jakarta: Rajawali Pers, 1985)

Soerjono Soekanto, Pengantar Penelitian Hukum, (Jakarta: UIPress, 1982)

Soetojo Prawiro Hamidjojo dan Marthalina Pohan, Hukum Orang dan Keluarga (Personene and Familie -Rect) (Surabaya: Ailaangga University Press, 1991)

Subekti, Pokok-pokok Hukum Perdata, (Jakarta: PT. Intermasa, 2001), Cet. XXIX

Sulaiman Rasjid, Fiqih Islam, (Bandung: Sinar Baru Algensindo, 2009), hlm. 380.

Sultan al-Ulama 'Izz al-Din Abd al'Aziz bin 'Abd al-Salam al-Silmi (selanjutnya disebut 'Izz al-Din saja), al-Qawa'id al-Kubra, (Damaskus: Dar al-Fikr, $1416 \mathrm{H}$ )

Syamsul Bahri,dkk, Metodologi Hukum Islam, (Yogyakarta: Teras 2008 Team Nusantara, Kitab Undang-Undang Hukum Perdata (Jakarta: Nusantara Publisher, 2009)

Tihami dan Sohari Sahrani, Fikih Munakahat, (Jakarta: PT. RajaGrafindo Persada, 2010)

..........,Fikih Munakahat: Kajian Fikih Nikah Lengkap, (Jakarta: PT. Raja Grafindo Persada, 2009)

Titik Triwulan Tutik, Hukum Perdata dalam Hukum Nasional, (Jakarta: Kencana Premada Media Group, 2008)

Uswatun Hasanah, Nikah Mut'ah Riwayatmu Kini (Tela'ah Tentang PelaksanaanSunnah Nikah Mut'ah Melalui Pendekatan Hadits Dan Sirah 
Nurhadi; Maqashid Syari'ah Hukum Perkawinan Dalam Kompilasi Hukum Islam (KHI)

Nabawiyah) (Fakultas Ushuluddin \& Pemikiran Islam, UIN Raden Fatah Palembang, Al-Fikra: Jurnal IImiah Keislaman, Vol. 16, No. 1, Januari - Juni, 2017 (45 - 72).

Wael B. Hallaq, A History Of Islamic Legal Theories, Sejarah Teori Hukum Islam, Pengantar Untuk Ushul Fiqh Mazhab Sunni, Penerjemah E.Kusnadiningrat dan Abdul Haris Bin Wahid, (Jakarta: PT. Raja Grafindo Persada, 2001)

Wahbah al Zuhaili, Al Figh al Islami wa Adillatuhu, (Damaskus: Dar al Fikr, 2004), Cet. IV, Juz IX

........, Al-Wajiz fi Ushul al-Figh, (Damaskus : Dar al Fikr, 2014)

Wasmandan Wardah Nuroniyah, Hukum Perkawinan Islam di Indonesia (Yogyakarta: Teras, 2011)

Wanjik Saleh, dikutip oleh Supriyadi, Dasar-Dasar Hukum Perdata Di Indonesia, (Kudus: CV. Kiara Science, 2015)

Yazid bin Abdul Qadir Jawas, Bingkisan Istimewa Menuju Keluarga Sakinah (Bogor-Jawa Barat: Penerbit Pustaka AtTaqwa, $\quad$ 1427H/Desember
2006), Cet Ke II Dzul Qa'dah, hlm. detail buku).

Yatimin dan Thamrin, Strategi Pembelajaran Akidah Akhlak Melalui Pendekatan Sufistik Untuk Madrasah Tsanawiyah Propinsi Riau (UIN Sultan Syarif Kasim Riau Pascasarjana UIN Sultan Syarif Kasim Riau yatiminmuhammad22@gmail.co m, husni023@gmail.com, AlFikra: Jurnal IImiah Keislaman, Vol. 16, No. 1, Januari - Juni, 2017 (152-172).

Zainuddin Ali,Hukum Perdata Islam di Indonesia (Jakarta: Sinar Grafika, 2007), cet. II

.........., Hukum Perdata Islam Indonesia. (Jakarta : Sinar Grafika, 2006)

Zuhdi A. Muhdlor, Memahami Hukum Islam, (Bandung: alBayyan, 1995)

Zulkayandri, Konsep Ihsan'Izz Al-Din Ibn Abd Al-Salam, (Dosen Fakultas Hukum dan Syariah UIN Suska Riau, Al-Fikra: Jurnal Ilmiah Keislaman, Vol. 4, No. 1, Januari-Juni 2005) 